University for Business and Technology in Kosovo

UBT Knowledge Center

Fall 9-2020

\title{
Cilësia dhe siguria e ushqimit nga këndvështrimi i konsumatorit në Kosovë
}

\author{
Liridona Neziri \\ University for Business and Technology - UBT
}

Follow this and additional works at: https://knowledgecenter.ubt-uni.net/etd

Part of the Food Science Commons

\section{Recommended Citation}

Neziri, Liridona, "Cilësia dhe siguria e ushqimit nga këndvështrimi i konsumatorit në Kosovë" (2020). Theses and Dissertations. 22.

https://knowledgecenter.ubt-uni.net/etd/22

This Thesis is brought to you for free and open access by the Student Work at UBT Knowledge Center. It has been accepted for inclusion in Theses and Dissertations by an authorized administrator of UBT Knowledge Center. For more information, please contact knowledge.center@ubt-uni.net. 


\section{UBI}

Kolegji UBT

Fakulteti: Shkencat e Ushqimit dhe Bioteknologji

Specializimi: Menaxhimi me Cilësinë dhe Sigurinë Ushqimore

\section{CILËSIA DHE SIGURIA E USHQIMIT NGA KËNDVËSHTRIMI I KONSUMATORIT NË KOSOVË}

Shkalla Bachelor

Liridona Neziri

Shtator/ 2020

Prishtinë 


\section{UBI}

Kolegji UBT

Fakulteti:Shkencat e Ushqimit dhe Bioteknologji

Specializimi: Menaxhimi me Cilësinë dhe Sigurinë Ushqimore

Punim Diplome

Viti akademik 2017-2018

Liridona Neziri

\section{CILËSIA DHE SIGURIA E USHQIMIT NGA KËNDVËSHTRIMI I KONSUMATORIT NË KOSOVË}

Mentori: Dr.sc.Hyrije Koraqi

Shtator / 2020

Ky punim është përpiluar dhe dorëzuar në përmbushjen e kërkesave të pjesshme për Shkallën Bachelor 


\section{ABSTRAKT}

Në shumicën e vendeve të zhvilluara, rregullorja e sigurisë ushqimore është përqendruar në vendosjen e standardeve që specifikojnë se si duhet të prodhohen produktet ushqimore dhe nivelin e tyre përfundimtar të sigurisë. Siguria e ushqimit dhe mbrojtja e konsumatorit janë detyra të rëndësishme të disa organizatave ndërkombëtare, të tilla si Codex Alimentarius dhe Organizata Botërore për Shëndetin e Kafshëve që veprojnë sipas rregullave të WTO, WHO dhe FAO. Përsëritja e çështjeve që lidhen me përhapjen e ushqimit të dëmshëm për shëndetin, rastet e kontaminimit të ushqimit, shfaqjen e sëmundjeve të reja lidhur me ushqimit dhe ndotja e ekosistemeve nga substancë të huaja të cilat rezultojnë në ndotjen e zinxhirit ushqimor për shkak të ndotjes së mjedisit, ka një efekt të rëndësishëm në sjelljen e konsumatorëve në tregun e ushqimit.

Qëllimi i këtij studimi ka qenë identifikimi i njohurive të konsumatorëve rreth sigurisë dhe cilësisë së produkteve ushqimore, faktorët që ndikojnë në zgjedhjen e një produkti ushqimor si dhe elementet që konsumatorët i konsiderojnë si përfaqësues të një produkti ushqimor të sigurtë dhe cilësor. Të dhënat primare në këtë studim janë mbledhur nga intervistimi i 188 të anketuarve me anë të pyetësorëve online në aplikacionin Google Forms. Gjatë këtij studimi, do të informoheni rreth konceptit të cilësisë dhe sigurisë ushqimore, mjeteve që përdoren për identifikimin e nevojave të konsumatorëve si dhe për raportin se si qëndrojnë konsumatorët në territorin e Kosovës krahas informacioneve rreth sigurisë dhe cilësisë ushqimore që ata kanë.

Të gjitha analizat statistikore nga pyetësori janë punuar duke përdorur programi MS Excel. 


\section{MIRËNJOHJE/FALENDERIME}

.........falënderoj më të dashurit e mi, familjen time dhe shoqerinë, për përkushtimin dhe durimin e tyre gjatë kësaj periudhe, shumë të rëndësishme për mua.

Faleminderit të gjithëve që ishit pranë meje! 


\section{PËRMBAJTJA}

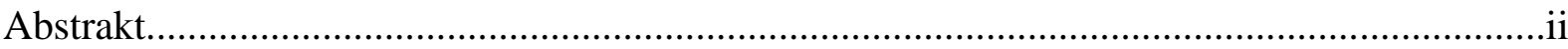

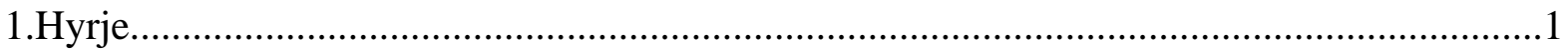

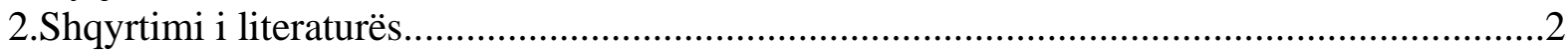

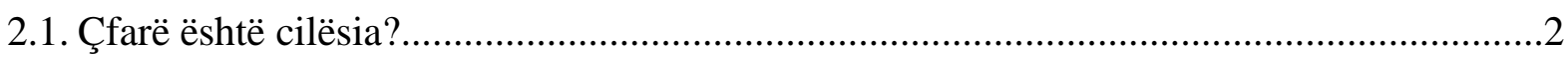

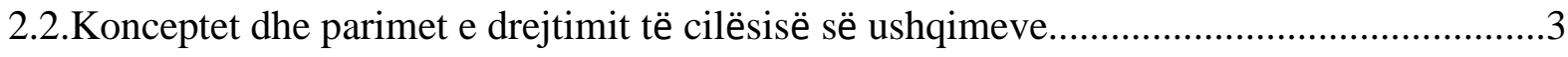

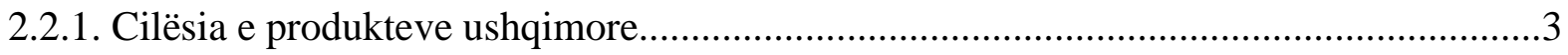

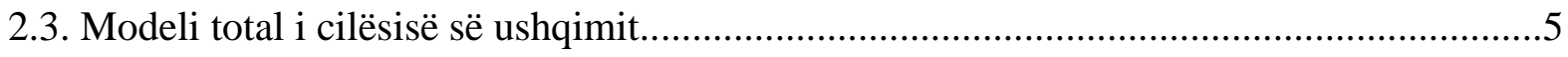

2.3.1. Mjetet në lidhje me Modelin Total të Cilësisë së Ushqimit......................................7

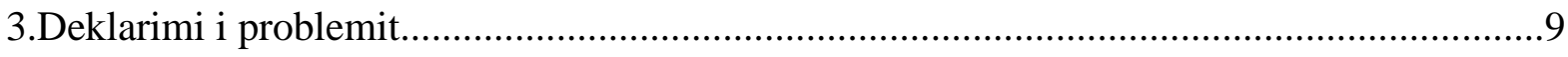

3.1. Përceprimi i cilësisë dhe sigurisë së ushqimit......................................................

3.1.1. ISO 22000 - Sistemi i Menaxhimit të Sigurisë Ushqimore.......................................10

3.1.2. HACCP - Analiza e Rreziqeve dhe Pikave Kritike të Kontrollit..............................12

3.2. Evolucioni i cilësisë dhe sigurisë së produkteve ushqimore........................................13

3.3.Cilësia e shërbimit dhe kënaqësia e klientit.............................................................16

4. Metodologjia e hulumtimit....................................................20

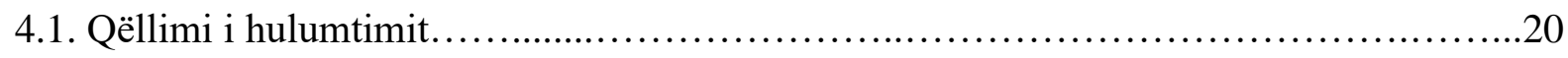

4.2. Objektivat e hulumtimit................................................. 20

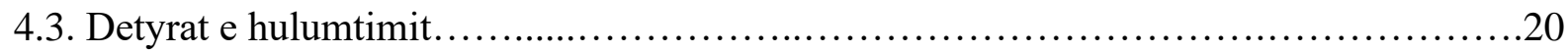

4.4. Metodat,teknikat dhe instrumentet e kërkimit(hulumtimit).. .........................21

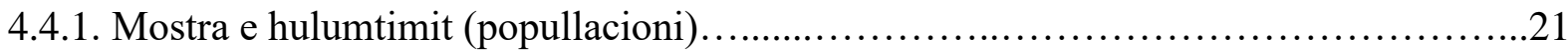

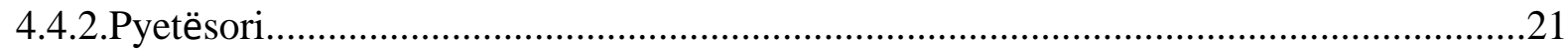

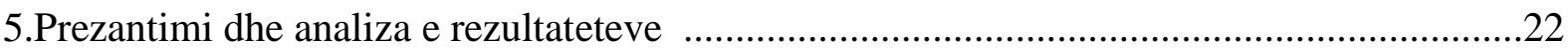

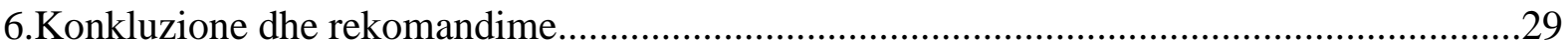

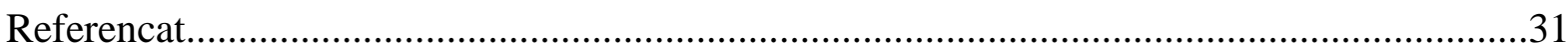




\section{LISTA E FIGURAVE}

Figura 1. Llojet e cilësisë së ushqimit..............................................................

Figura 2. Modeli Total i Cilësisë së Ushqimit..................................................6

Figura 3. Modeli I cilësisë së shërbimit Grönroos (1990).........................................17

Figura 4. Modeli SERVQUAL (Parasuraman et al., 1988)...........................................18 


\section{LISTA E TABELAVE}

Tabela 1. Karakteristikat e të anketuarve.....................................22 


\section{FJALORI I TERMAVE}

WTO - World Trade Organization

WHO - World Health Organization

FAO - Food and Agriculture Organization of the United Nations

OMGJ - Organizmat e Modifikuar Gjenetikisht

ISO - International Organization for Standardization

BSE - Bovine Spongiform Encephalopathy

SHBA - Shtetet e Bashkuara të Amerikës

BE - Bashkimi Evropian

PDO - Protected Designation of Origin

PGI - Protected Geographical Indication

TSG - Traditional Specialities Guaranteed 


\section{HYRJE}

Shqetësimet në rritje lidhur me aplikimin e pesticideve shumë toksike dhe kërkesat në rritje për ushqim e drejtojnë vëmendjen tonë drejt sigurisë së ushqimit si dhe në rregullimnin global të prodhimit të ushqimit (Dou et al., 2015). Popullsia në tërësi, individët dhe familjet si grupe sociale, të cilat blejnë produkte për konsumin e tyre personal krijojnë tregun e përgjithshëm. Cdo person vendos për blerjen e gamës së produkteve ushqimore në baza rutinore (Kubicová dhe Kádeková, 2011). Poashtu, në ditët e sotme konsumatorët janë më të shqetësuar për sigurinë e produkteve ushqimore për shkak të një seri skandalesh ushqimore që kanë ndodhur gjatë dekadës së fundit dhe për shkak të faktit se nuk ka shenja të uljes së shpeshtësisë së shfaqjes së skandaleve të ushqimit (Loc, 2006). Që sistemi i sigurisë së produkteve ushqimore të jetë sa më efikas, institucionet shtetërore dhe ato të financuara nga shteti kontribuojnë në krijimin e legjislacionit, sigurinë e vazhdueshme dhe rigoroze të shëndetit dhe kontrollin e cilësisë, aplikimin e njohurive shkencore në praktikë dhe edukimin e konsumatorëve në fushën e ushqimit.

Në shumicën e vendeve të zhvilluara, rregullorja e sigurisë ushqimore është përqendruar në vendosjen e standardeve që specifikojnë se si duhet të prodhohen produktet ushqimore dhe nivelin e tyre përfundimtar të sigurisë (Rouvière dhe Caswell, 2012). Siguria e ushqimit dhe mbrojtja e konsumatorit janë detyra të rëndësishme të disa organizatave ndërkombëtare, të tilla si Codex Alimentarius dhe Organizata Botërore për Shëndetin e Kafshëve që veprojnë sipas rregullave të WTO, WHO dhe FAO (Šinková, 2007).

Përsëritja e çështjeve që lidhen me përhapjen e ushqimit të dëmshëm për shëndetin, rastet e kontaminimit të ushqimit, shfaqjen e sëmundjeve të reja lidhur me ushqimit dhe ndotja e ekosistemeve nga substancë të huaja të cilat rezultojnë në ndotjen e zinxhirit ushqimor për shkak të ndotjes së mjedisit, ka një efekt të rëndësishëm në sjelljen e konsumatorëve në tregun e ushqimit (Skořepa, 2003). 


\section{SHQYRTIMI I LITERATURËS}

\section{1. ÇFARË ËSHTË CILËSIA?}

Ekziston një marrëveshje e përgjithshme që cilësia ka një dimension objektiv dhe subjektiv. Në dimensionin objektiv, cilësia i referohet karakteristikave fizike që ndodhen në produkt dhe zakonisht trajtohen nga teknologët e ushqimit. Cilësia subjektive është cilësia siq perceptohet nga konsumatorët. Marrëdhënia mes prodhuesve dhe konsumatorëve është kruciale për cilësinë pasi që vetëm kur prodhuesit mund të përkthejnë dëshirat e konsumatorëve në karakteristika fizike të produktit dhe vetëm kur konsumatorët konstatojnë cilësi të dëshiruar nga mënyra se si është ndërtuar produkti, cilësia do të jetë parametër konkurrues për prodhuesit e ushqimit.Në dimensionin subjektiv, ekzistojnë dy pikëpamje të ndryshme për cilësinë. E para, të cilën mund ta quajmë qasje gjithëpërfshirëse, barazon cilësinë me të gjitha vetitë e dëshirueshme që një produkt është perceptuar të ketë. E dyta, të cilën mund ta quajmë qasje të ekselencës, sugjeron që produktet mund të kenë veti të dëshirueshme që konsumatorët nuk i shohin si pjesë të cilësisë Cilësia e orientuar drejt produktit mbulon të gjitha aspektet fizike të produktit që së bashku japin një përshkrim preciz të produktit specifik. Shembuj të cilësisë së produktit mund të jenë përqindja e yndyrës dhe muskujve, madhësia e mishit, përmbajtja e amidonit në patate si dhe fortësia e birrës.Cilësia e orientuar drejt procesit përfshin mënyrën e prodhimit të produktit ushqimor si p.sh. pa pesticide, sipas rregulloreve për mirëqenien e kafshëve, prodhim organic etj. Përshkrimet e bazuara në këto aspekte japin informacione rreth procedures së përdorur për të krijuar produktin përfundimtar dhe këto aspekte jo domosdoshmërisht mund të kenë ndonjë efekt në vetitë fizike të produktit.Lloji i tretë i cilësisë është kontrolli i cilësisë, të cilin ne e përcaktojmë si standardet që një produkt duhet të përmbushë në mënyrë që të miratohet për një klasë specifike të cilësisë. Disa shembuj mund të jenë standardi për peshën e vezëve për klasifikime të madhësive të ndryshme, klasifikimi EUROP i mishit etj. Skemat e çertifikimit të cilësisë si ISO 9000 merren kryesisht me kontrollin e cilësisë. Kontrolli i cilësisë merret me respektimin e standardeve specifike për produktin dhe cilësinë e orientuar drejt procesit.Cilësia e orientuar nga konsumatori është perceptimi i cilësisë subjektive nga këndvështrimi i konsumatorit; një konsumator mund të jetë përdoruesi i fundit ose një përdorues i ndërmjetëm në zinxhirin ushqimor, p.sh., shitës me pakicë. 


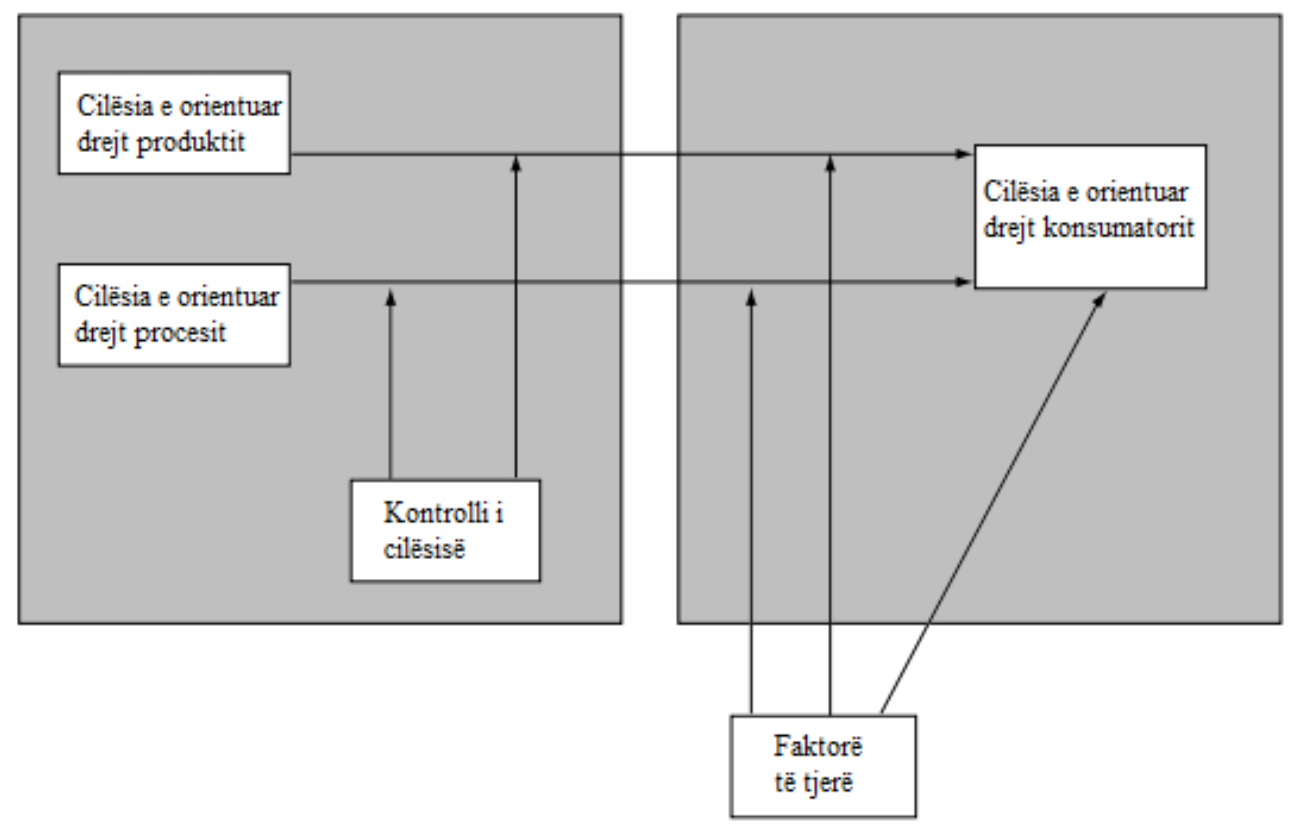

Figura 1. Llojet e cilësisë së ushqimit

\subsection{KONCEPTET DHE PARIMET E DREJTIMIT TË CILËSISË SË USHQIMEVE}

Cilësia është një karakteristikë dalluese, me rëndësi të veçantë në vlerësimin dhe konkurrueshmërinë e produkteve ushqimore, në tregun botëror.Të përftosh një produkt përfundimtar me cilësi të mirë, do të thotë që ta drejtosh dhe mbikëqyrësh atë (cilësinë e tij), për gjatë gjithë zinxhirit ushqimor: që nga furnizuesi i lëndëve të para dhe deri tek konsumatori. Kuptimi i konsumatorit për cilësinë dhe kërkesat, që ai ka në lidhje me sigurinë ushqimore, e cila është e lidhur në mënyrë të drejtpërdrejtë me shëndetin e tij, detyrojnë operatorët (punonjësit) e agrobiznesit dhe të industrisë ushqimore, të përdorin drejtimin (menaxhimin) e cilësisë si një objektiv strategjik në prodhim dhe në kërkimet e tyre më të reja.

\subsubsection{Cilësia e produkteve ushqimore}

Drejtimi i cilësisë ka një rëndësi të veçantë sidomos në fushën e Agrobiznesit dhe të Industrisë Ushqimore. Konsumatori ka një lidhje emocionale me produktet ushqimore. Ushqimi është diçka, që ai e fut brenda trupit të tij çdo ditë, gjatë gjithë jetës dhe është i lidhur në mënyrë të 
drejtpërdrejtë dhe jo të drejtpërdrejtë me mirëqenien dhe shëndetin e tij. Siguria dhe shëndeti i produkteve ushqimore janë problem të një rëndësie të veçantë. Tradicionalisht, drejtimi i cilësisë në produktet ushqimore ka qenë i fokusuar në problemet e sigurisë ushqimore. Në ditët tona, koncepti i cilësisë është zgjeruar në të gjitha aspektet e produktit ushqimor.Industrializimi shoqëror, i ndjekur nga shtrirja e madhe dhe llojshmëria e sistemeve të prodhimit ushqimor, mund të përbëjë rrezik për një numër të madh konsumatorësh (p.sh. një produkt i ndotur aksidentalisht në një raft supermarketi). Prandaj, cilësia duhet të ndërtohet në sistemet e prodhimit, me qëllim që të parandalojë rreziqet e mundshme, më mire se sa të korrigjojë apo rregullojë gabimet. Siguria dhe lidhja e saj me shëndetin e produkteve ushqimore, shpesh nuk janë karakteristika të dukshme dhe konsumatori është i detyruar të besojë në informacionin, që atij ia siguron prodhuesi. Megjithatë, një nga arritjet më të mëdha të situatës aktuale, është ajo që në shumicën e vendeve perëndimore, ekziston një lidhje besimi ndërmjet konsumatorëve dhe prodhuesve të produkteve ushqimore.

Hoogland dhe autorë të tjerë (1998), kanë përmendur disa veçori, që janë karakteristike për drejtimin e cilësisë së produkteve ushqimore, si:

- Produktet bujqësore prishen shpejt dhe janë subjekt i një zbërthimi të shpejtë, si pasojë e proceseve fiziologjike dhe ndotjeve mikrobiologjike. Këto procese, mund të rrezikojnë shëndetin e njeriut dhe për kontrollin e cilësisë së tyre, nevojitet një njohje e thellë e vetive të produktit;

- Shumica e produkteve bujqësore janë heterogjene përsa u përket parametrave të tyre, si: përmbajtja e përbërësve të rëndësishëm (p.sh. sheqernat, yndyrnat, proteinat), madhësia dhe ngjyra. Lloji i variacionit është i varur p.sh. nga ndryshimet e kultivarit dhe karakteristikat sezonale, të cilat nuk mund të kontrollohen plotësisht;

- Prodhimi parësor i produkteve bujqësore, që kryhet nga një numër fermash, të cilat operojnë në shkallë të ulët, e bëjnë kontrollin më të komplikuar.

Përveç këtyre aspekteve tipike, për produktet agro - ushqimore, ka disa arsye dhe fakte, që theksojnë nevojën e drejtimit të cilësisë në mënyrën e duhur. Përparimet e vazhdueshme në shkencën mjekësore, shkencën e ushqimit dhe teknologjinë e prodhimit ushqimor, kanë bërë që të konstatohen një numër sëmundjesh të shkaktuara nga ushqime me prani të patogjenëve të ndryshëm dhe këto prekje vazhdojnë të jenë ende një problem I madh për shëndetin dhe 
rëndësinë ekonomike. Në vitin 1990, në 100.000 vetë, për sëmundje nga ushqime jo të sigurta, u raportuan 120 raste, nga 11 vende Evropiane, të paktën 30.000 raste në 100.000 banorë, paraqiten me probleme gastrike. Megjithatë, vetëm një pjesë e vogël e rasteve aktuale të prekjes nga ushqimet, i janë nënshtruar inspektimit ushqimor, kontrollit të agjencive të shëndetit. Kjo thekson urgjencën për një vëmendje më të lartë në kontrollin dhe sigurinë e produkteve ushqimore.Sot, në mbarë botën, kërkesat e konsumatorit për produkte të sigurta po vijnë gjithnjë në rritje dhe prirjet janë drejt konsumimit të produkteve të freskëta, me aroma dhe shije natyrale dhe jo të paketuara për një kohë të gjatë.Ndryshime të rëndësishme janë duke u bërë edhe në sistemet e prodhimit të ushqimit, p.sh. në mbarështimin e kafshëve. Në fokus është ndryshimi nga prodhimi sasior në atë cilësor, duke bërë më shumë përpjekje, p.sh. në lidhje me kujdesin ndaj kafshës dhe përdorimin e reduktuar të mjekimeve veterinare. Një fushë tjetër, që kërkon vëmendje të veçantë, është përdorimi i gjerë i një numri të madh lëndësh të papërpunuara dhe produktesh nga vende të ndryshme të botës. Kjo ka rritur potencialin për një shpërndarje gjeografike të sëmundjeve të shoqëruara me ndotës dhe patogjenë të veçantë.

\subsection{MODELI TOTAL I CILËSISË SË USHQIMIT}

Modeli Total i Cilësisë së Ushqimit, i propozuar fillimisht nga Grunert, Larsen, Madsen dhe Baadsgaard (1995), integron qasjet ndaj perceptimit të cilësisë. Përveç kësaj, ky model integrin dy elemente të tjera kryesore të teorisë së sjelljes së konsumatorit, gjegjësisht shpjegimin e synimit për blerje dhe shpjegimin e kënaqësisë së konsumatorit (Gardial, Clemons, Woodruff, Schumann \& Burns, 1994; Oliver, 1980, 1993; Woodruff \& Gardial, 1996). Modeli është treguar në figurën e mëposhtme.Para së gjithash, modeli i përgjithshëm i cilësisë së ushqimit bën dallimin midis vlerësimeve të blerjes "para" dhe "pas". Dallimi midis "para" dhe "pas" blerjes formon bazën e Modelit Total të Cilësisë së Ushqimit. Në pjesën “para blerjes”, modeli tregon se si formohen pritjet për cilësi bazuar në shenjat e cilësisë në dispozicion. Shenjat e cilësisë së brendshme mbulojnë karakteristikat fizike të produktit dhe lidhen me specifikimet teknike të produktit, të cilat gjithashtu përfshijnë karakteristikat e tij fiziologjike, që do të thotë karakteristikat që mund të maten në mënyrë objektive. Shenjat e cilësisë së jashtme paraqesin të gjitha karakteristikat e tjera të produktit, siç janë emri i markës, çmimi, shpërndarja, paketimi. Mënyra se si konsumatorët përdorin shenjat e cilësisë për të konstatuar cilësinë e pritur mund të jenë mjaft të ndërlikuara dhe nganjëherë duket të jenë mjaft iracionale. Për shembull, konsumatorët përdorin ngjyrën e mishit për të konstatuar butësinë e tij, konsistencën e kosit për 
të konstatuar shijen dhe paketimin në shishe të xhamit (krahasuar me materialet tjera) për të konstatuar cilësinë e produktit. Në shumicën e rasteve, vendimet të cilat konsumatorët i zgjedhin në raport me produktin që synojnë për të blerë ndikohen nga situata e blerjes (informacioni që gjendet në dyqan, fakti nëse blerjet janë të planifikuara ose spontane, presioni kohës gjatë blerjes etj.). Sipas Modelit Total të Cilësisë së Ushqimit, cilësia nuk është qëllim në vetvete pasi që ndihmon në plotësimin e motiveve dhe vlerave të blerjes. Prandaj, ky model

Figura 2. Modeli Total i Cilësisë së Ushqimit

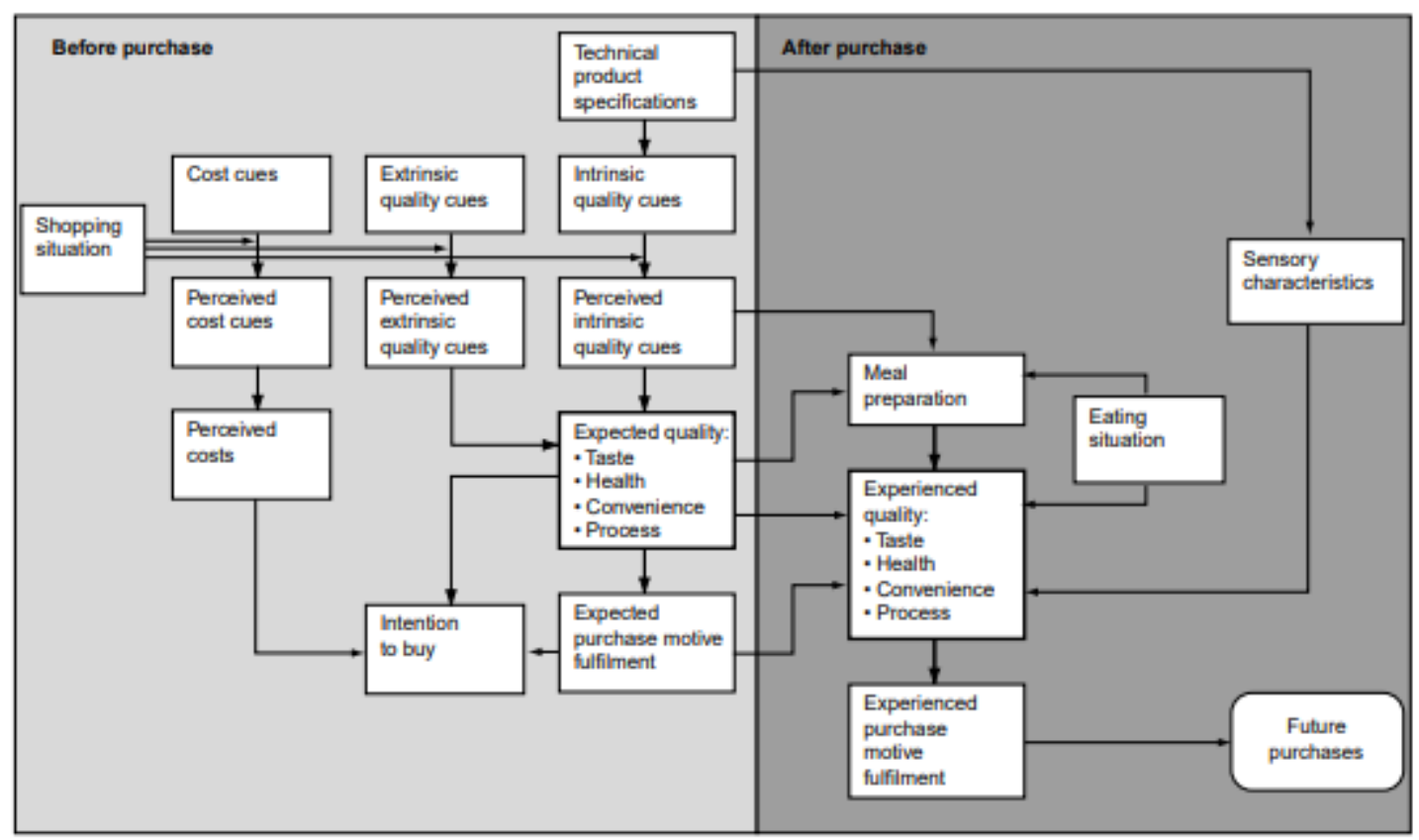

përfshin përmbushjen e motiveve ose vlerave se si produktet ushqimore kontribuojnë në arritjen e vlerave të dëshiruara. Cilësia e parashikuar dhe përmbushja e kërkesave të tyre përbëjnë rezultatet pozitive që konsumatorët presin nga blerja e një produkti ushqimor. Pas blerjes, konsumatori do të ketë një përvojë rreth cilësisë së produktit e cila shpesh devijon nga cilësia e pritur. Vetë produkti, veçanërisht karakteristikat e tij shqisore është padyshim një përcaktues por ka edhe shumë të tjera (mënyra se si është përgatitur produkti, disponimi i konsumatorit, përvoja e mëparshme etj.). Poashtu, pritshmëria në produktin e caktuar mund të jetë gjithashtu një variabël e rëndësishme në përcaktimin e përvojës rreth cilësisë së produktit (Deliza \& MacFie, 1996; Oliver, 1993; Schifferstein, 2001). Marrëdhënia midis pritjes së cilësisë dhe përvojës rreth cilësisë besohet se përcakton kënaqësinë e konsumatorit për produktin e caktuar dhe rrjedhimisht vendos për mundësinë e blerjes së produktit përsëri. 


\subsubsection{Mjetet në lidhje me Modelin Total të Cilësisë së Ushqimit}

Duke pasur parasysh natyrën e gjerë të Modelit Total të Cilësisë së Ushqimit, e gjithë sfera e metodave të shkencave sociale mund të zbatohen si mjete për identifikimin e nevojave të konsumatorëve.Forma e teknikës së intervistës është mjeti kryesor që përdoret për identifikimin e nevojave të konsumatorit. Në aspektin kualitativ, kryesisht përfitohen informacione për të marrë një kuptim themelor të dimensioneve të cilësisë, për motivet e blerjes, për situatat e blerjes etj. Ndërsa, në aspektin kuantitativ, metodat e pyetësorit përdoren si në sondazhe ashtu edhe në eksperimente të ndryshme. Shkallëzimi është një teknikë kualitative e intervistës e cila merret me shpjegimin e sjelljes së konsumatorit (Grunert, Beckmann \& Sorensen, 2001; Grunert \& Grunert, 1995; Reynolds \& Gutman, 1988). Qëllimi i këtij mjeti është të zbulojë marrëdhëniet hierarkike midis atributeve të produkteve të caktuara, pasojave të këtyre atributeve për konsumatorin dhe ndikimin e tyre në mendjen e konsumatorit. Një intervistë e këtij lloji përbëhet nga dy hapa:

Së pari, duhet të identifikohen atributet e produktit përkatës. Kjo realizohet me anë të pyetjeve të drejtpërdrejta që i drejtohen konsumatorëve, klasifikimit triadik ose metodave të tjera që përdoren për të identifikuar atributet më të rëndësishme për konsumatorët. Pas identifikimit të atributeve më të spikatura, të anketuarit pyeten për preferencat e tyre dhe arsyet se pse i preferojnë atributet e caktuara. Të dhënat e mbledhura analizohen nga përmbajtja dhe përpunohen duke treguar lidhjet kryesore midis atributeve, pasojave dhe vlerave të produkteve për nje grup të anketuarve. Analiza e përbashkët është një teknikë që përdoret gjerësisht në hulumtimin e konsumatorëve, ku të anketuarve u paraqiten përshkrimet e produktit të gjeneruara sipas një modeli të atributeve të produktit (Brice, 1997; Caroll \& Green, 1995; Green \& Srinivasan, 1978, 1990; Louviere, 1994; Wittink, Vriens \& Burhenne, 1994). Të anketuarit vlerësojnë përshkrimet e ndryshme të produktit ose bëjnë një zgjedhje midis tyre dhe përgjigjet që rezultojnë përdoren për të konstatuar sesi atributet e ndryshme kontribuojnë në vlerësimin e përgjithshëm. Në kontekstin e Modelit Total të Cilësisë së Ushqimit, kjo metodë ka për detyrë të analizojë marrëdhëniet midis sugjerimeve dhe cilësisë së pritshme në njërën anë dhe qëllimit të blerjes në anën tjetër. Dallimi midis proceseve të vlerësimit të cilësisë para dhe pas blerjes luan një rol të madh në Modelin Total të Cilësisë së Ushqimit. 


\section{DEKLARIMI I PLOBLEMIT}

\subsection{PERCEPTIMI I CILËSISË DHE SIGURISË SË USHQIMIT}

Siguria e ushqimit mund të përkufizohet në kuptimin e gjerë dhe të ngushtë (Ritson dhe Mai, 1998). Në kuptimin e ngushtë, siguria e ushqimit mund të përkufizohet si e kundërta e rrezikut të ushqimit, pra si pamundësi e paraqitjes të ndonjë sëmundjeje, si pasojë e konsumimit të një ushqimi të caktuar. Në kuptimin e gjerë, siguria e ushqimit mund të përfshijë gjithashtu vlerat nutritive të produktit ushqimor të caktuar dhe shqetësimet që kanë lidhje me produktet ushqimore. Ashtu si me cilësinë e ushqimit edhe në aspektin e sigurisë së ushqimit dallojmë dimensionin objektiv dhe subjektiv. Siguria ushqimore në dimensionin objektiv është një koncept i bazuar në vlerësimin e rrezikut të konsumimit të një produkti ushqimor të caktuar. Ndërsa, në dimensionin subjektiv siguria e ushqimit perceptohet nga mendja e konsumatorit.

A është siguria vetëm një dimension tjetër i cilësisë? Përkufizimi ynë i gjerë për cilësinë e ushqimit si gjithçka që një konsumator do ta konsideronte të dëshirueshme në një produkt ushqimor do të sugjeronte që siguria është një dimension tjetër i cilësisë. Sidoqoftë, studimet rreth perceptimit të cilësisë së ushqimit sugjerojnë që siguria nuk është faktori më i rëndësishëm në mendjen e konsumatorëve kur iu kërkohet të përshkruajnë pikëpamjen e tyre rreth cilësisë së ushqimit (Brunsø et al., 2002). Kjo mund të sugjerojë që perceptimi i sigurisë ushqimore të ndikojë në zgjedhjen e produkteve ushqimore nga konsumatori në mënyra të ndryshme nga perceptimi i dimensiove tjera të cilësisë që kemi përmendur më lart. Duket se perceptimi i sigurisë ushqimore luan një rol të rëndësishëm kryesisht në dy mënyra. Së pari, në situate ku perceptohen problemet kryesore rreth sigurisë ushqimore, si BSE (Burton dhe Young, 1996), problem i dioksinave në Belgjikë (Verbeke, 2001) ose polemika Alar në SHBA (Herrmann et al., 1997). Perceptimi i rrezikut në produkte ushqimore mund të ndikojë në vendimet që i marrin konsumatorët për zgjedhjen e ushqimit ku në të shumtën e rasteve konsumatorët shmangin kategori ose marka të caktuara për disa kohë, derisa situata të kthehet në normalitet. Së dyti, konsumatorët i kushtojnë vëmendje sigurisë ushqimore për teknologji të caktuara të prodhimit. Shembuj kryesorë janë rrezatimi i ushqimit dhe OMGJ - të. Në këto raste, konsumatorët i konsiderojnë këto teknika të caktuara të prodhimit si të pasigurta dhe vazhdimisht shfaqin qëndrime negative ndaj përdorimit të këtyre teknologjive. Industritë ushqimore dhe organet legjislative i marrin në konsideratë qëndrimet e tilla të konsumatorëve prandaj këto qëndrime kanë rezultuar në mos përdorimin e rrezatimit në disa vende dhe në një vonesë të 
konsiderueshme të adoptimit të OMGJ - ve në tregjet evropiane.

Perceptimi i rrezikut të konsumatorit është studiuar në terma më të përgjithshëm, duke filluar me punën e mirënjohur nga Slovic dhe kolegët (Fischhoff et al., 1978; Slovic, 1987). Tre fenomene që duket se janë të fuqishme do të përmenden këtu. Së pari, rreziku i vetë imponuar është më i pranueshëm për konsumatorët sesa rreziku i bazuar në teknologji, Pra, megjithëse përgatitja e produkteve ushqimore në shtëpi sipas standardeve objektive është shumë më e rrezikshme sesa prodhimi i produkteve ushqimore në një fabrikë, konsumatorët priren t’i perceptojnë ushqimet e gatshme si më të rrezikshme sesa produktet ushqimore që kanë përgatitur në shtëpi. Ky rrezik i perceptuar amplifikohet kur ka përdorim të teknologjive të reja dhe të panjohura. Së dyti, megjithëse konsumatorët zakonisht mund ta vlerësojnë rrezikun që lidhet me trajtimin e ushqimit të tyre në terma të përgjithshëm, ata besojnë se probabiliteti për t’u prekur vetë nga një problem i caktuar është më i ulët se sa probabiliteti që konsumatori mesatar të preket nga i njëjti problem. Në fund, rëndësia e dimensioneve të frikës në perceptimin e rreziqeve është demonstruar mjaft shumë, duke nënkuptuar që rreziqet e njohura perceptohen si më pak të rënda se ato të panjohura. Ky është një femonem i rëndësishëm në perceptimim e OMGJ - ve dhe disa produkteve ushqimore.

\subsubsection{ISO 22000 - Sistemi i Menaxhimit të Sigurisë Ushqimore}

Familja e Standardeve Ndërkombëtare ISO 22000 adreson menaxhimin e sigurisë ushqimore. Pasojat e ushqimit jo të sigurt mund të jenë serioze dhe Standardet ISO të menaxhimit të sigurisë ushqimore ndihmojnë organizatat të identifikojnë dhe kontrollojnë kërcënimet e sigurisë ushqimnore. Ndërsa shumë prej produkteve të sotme ushqimore vazhdimisht kapërcejnë kufijtë kombëtare, Standardet Ndërkombëtare nevojiten për të mundësuar sigurinë e zinxhirit global të sigurisë ushqimore. ISO 22000:2005 përcakton kërkesat për një sistem të menaxhimit të sigurisë ushqimore dhe mund të certifikohet. Ai hartëzon atë çfarë i nevojitet të bëjë organizata për të treguar aftësinë e saj për të kontrolluar kërcënimet ndaj sigurisë ushqimore në mënyrë që të garantojë se ushqimi është i sigurt. Ai mund të përdoret nga çdo lloj organizate, pavarësisht madhësisë së saj apo pozicionimit në zinxhirin ushqimor. Industria globale e ushqimit është nën presion nga një numër i madh standardesh private për sigurinë ushqimore të cilat duhet ti marrin paraysh furnitorët në industrinë ushqimore dhe të certifikohen me to në mënyrë që të mund të shesin produktet e tyre. Rritja e kostove të certifikimit e kombinuar me kërkesat jo

fleksible në standarded private detyron rritjen e kostove pa kontribuar në rritjen e sigurisë 
ushqimore. Si një alternativë ndaj këtyre zhvillimeve, nevojitet një standard i mirë hartuar dhe i respektueshëm siç është ISO 22000. Kombinimi i ISO 22000 dhe ISO TS 22002-1 njihet nga shumica e operatorëve në tregun global ushqimor, përfshirë edhe GFSI. Në disa vende, autoritetet ushqimore pranojnë ISO 22000 për certifikimin e palëve të treta të operatorëve të biznesit ushqimor. Me rritjen e fokusit në standarded globale, operatorët e biznesit ushqimor do të jenë në gjendje të konkurojnë në planin ndërkombëtar mbi kushte të barabarta. Në të ardhmen, si autoritetet kombëtare dhe ato ndërkombëtare si dhe klientët do të fokusohen në integrimin e menaxhimit të sigurisë ushqimore në të gjithë zinxhirin ushqimor, nga ferma në tavolinë, duke përqafuar një qasje të orientuar drejt riskut. ISO 22000 mund të përdoret nga organizatat në të gjithë zinxhirin ushqimor. Ai krijon një strukturë ideale për vendosjen e principeve, procedurave dhe udhëzuesve të cilët përputhen me zinxhirin ushqimor, ndërkohë që përmirësojnë menaxhimin e kosto - efektivitetit në industri. Për më tepër, ai përmirëson mjetet praktike të nevojshme për menaxhimin e sigurisë ushqimore si një sistem i vetëm koherent.

\section{Cilat janë përfitimet e ISO 22000 - Sistemit të Menaxhimit të Sigurisë Ushqimore?}

- Zbatimi i standardit në të gjithë zinxhirin ushqimor

- Rrit garancinë në sigurinë e produkteve

- Dokumentimi i sigurisë ushqimore

- Vë theksin në parandalim në vend të korrigjimit të garancisë së sigurisë

- Eficiencë në kontrollin e kostove, që rrezulton nga minimizimi i kërcënimeve në ushqim

- Zvogëlimi i sasisë së produkteve që janë pa specifikime

- Zhvillimi i dokumentacioneve për përputhshmërinë ligjore

- Përdorim më i mirë i burimeve

- Përmirësimi i imazhit të organizatës

- Promovimi i tregëtisë së shëndetshme në nivel ndërkombëtar.

\subsubsection{HACCP - Analiza e Rreziqeve dhe Pikave Kritike të Kontrollit}

HAACP është metodë për të mundësuar sigurinë e ushqimit duke shqyrtuar çdo hap në një operacion ushqimor, duke identifikuar hapat që janë kritikë për sigurinë e ushqimit dhe zbatimin e procedurave efektive të kontrollit dhe monitorimit në këto hapa. Në këtë mënyrë, 
HACCP përpiqet të shmangë rreziqet në vend në vend që të përpiqet të inspektojë produktet përfundimtare. Poashtu, mund të përdoret në të gjitha fazat e zinxhirit ushqimor, nga prodhimi dhe proceset e përgatitjes së ushqimit duke përfshirë paketimin, shpërndarjen etj. Metodologjia e HACCP-it normalisht përshkruhet në 12 hapa:

- Ekipa HACCP

- Përshkrimi i produkteve/karakterizimi

- Identifikimi i qëllimit të përdorimit të produktin

- Ndërtimi i diagrameve rrjedhëse

- Verifikimi në vend i diagrameve rrjedhëse

- Identifikimi dhe analiza e rrezikut

- Identifikimi i pikave kritike të kontrollit

- Vendosja e kufinjëve kritik

- Vendosja e sistemit të monitorimit

- Vendosja e aksioneve korrigjuese

- Vendosja e procedurave të verifikimit, validimit dhe rishikimit

- Dokumentacioni dhe regjistrimet. 


\subsection{EVOLUCIONI I CILËSISË DHE SIGURISË SË PRODUKTEVE USHQIMORE}

Gjatë dekadave të fundit ka pasur një rritje të kërkesave për ushqime të sigurisë së lartë. Zhvillimi i shpejtë ekonomik dhe ndryshimet e fundit në zinxhirin e furnizmit ushqimor kanë kontribuar në rritjen e interest për çështjen e cilësisë në sektorin e ushqimit. Në mendjen e konsumatorëve, koncepti i cilësisë së një produkti ushqimor duket se është i lidhur ngushtë me perceptimin e të qenit i sigurt. Një studim i kohëve të fundit, duke hetuar marrëdhëniet midis cilësisë së ushqimit dhe sigurisë së ushqimit ka zbuluar se njerëzit duket se janë më të prirur të konsiderojnë një produkt ushqimor si të sigurt nëse e konsiderojnë atë të cilësisë së lartë (Van Rijswijk \& Frewer, 2008). Shqetësimi në lidhje me sigurinë dhe cilësinë e produkteve ushqimore përfshin çdo fazë të zinxhirit të prodhimit. Debati rreth këtyre temave është përqendruar në disa aspekte të produktit: nga karakteristikat organoleptike deri tek sigura e shëndetit dhe higjienës, nga shëndetësia dhe vetitë ushqyese deri tek vendi i prodhimit dhe aspektet tjera të lidhura me të. Përballë kërkesave për siguri dhe informacion shtesë duke kërkuar gjithnjë e më shumë konsumatorë, organet publike evropiane dhe vendore janë përgjigjur me miratimin e legjislacionit siç janë standardet që lidhen me gjurmueshmërinë dhe etiketimin e produkteve (Savov \& Kouzmanov, 2009). Për të garantuar cilësi dhe siguri të produkteve, janë futur në përdorim një sërë rregulloresh ndërkombëtare, duke përfshirë standardet ISO 9001 (Organizata Ndërkombëtare për Standardizim), e cila përcakton kërkesat që duhet të ketë një sistem i cilësisë për të siguruar kontrollin në të gjithë procesin e prodhimit. Për parandalimin ose zbulimin e parregullësive sa i përket mjeteve operative ekziston sistemi HACCP (Analiza e Rrezikut dhe Pikave Kritike të Kontrollit), qëllimi i të cilit është të arrijë objektivat e vetë kontrollit (Pham, Jones, Sargeant, Marshall \& Dewey, 2010; Ramphal \& Simelane, 2010). Certifikimi dhe marka u sigurojnë konsumatorëve një sërë indikacionesh në lidhje me jo vetëm origjinën e produktit, por edhe për proceset përkatëse të prodhimit dhe aspektet e tjera duke përfshirë aspektet e sigurisë mjedisore dhe etike. Të gjitha këto përbëjnë thelbin e konceptit të cilësisë (Marino \& Nobile, 2007). Një studim I Eurobarometrit I realizuar në vitin 2012 ka treguar që konsumatorët italianë janë më të vëmendshëm ndaj etiketave të cilësisë në Evropë, ku 35 \% të anketuarve italianë deklarojnë se në kohën e blerjes ata gjithmonë kontrollojnë nëse produkti ushqimor ka etiketa të cilësisë që garantojnë karakteristika specifike. 
Kjo përqindje është më e lartë se shifra mesatare evropiane prej $22 \%$ (BE, 2012). Përmes komunikimit dhe marketingut, ndërmarrjet ushqimore kanë inkurajuar lidhjen midis produkteve tradicionale të çertifikuar dhe organike nga njëra anë, ndërsa në anën tjetër cilësisë dhe sigurisë së lartë. Marka e çertifikuar supozohet se iu siguron konsumatorëve një mënyrë miqësore për të zgjedhur një produkt të besueshëm, veçanërisht gjatë një kohe kur frika ndaj ushqimit është shumë e lartë dhe konsumatorët po tregojnë më pak besim në proceset e prodhimit, produktet e importuara dhe efektivitetin e proceseve të kontrollit (Ferretti \& Magaudda, 2006). Diskutimet në lidhje me teknologjitë e reja të përdorura në sektorin e ushqimit, veçanërisht në lidhje me modifikimin gjenetik, kanë sjellë në fokus interesin e konsumatorëve për prodhimet ushqimore dhe mungesën e njohurive të përgjithshme për të (Grunert, 2002). Disa rreziqe ushqimore që kanë ndodhura nga fillimi i viteve '90, kanë tronditur konsumatorët dhe tërhoqën vëmendjen e tyre për rëndësinë e gjurmueshmërisë së ushqimit. Në ditët e sotme, për të përcaktuar cilësinë e produkteve ushqimore, konsumatorët vlerësojnë si karakteristikat e brendshme të produktit ashtu edhe karakteristikat e jashtme, siç janë gjurmueshmëria, origjina, indikacionet gjeografike dhe çertifikimi (Mascarello et al., 2015; Jover et al., 2004) dhe pastaj zgjedhin produktet ushqimore sipas elementeve që karakterizojnë vetë produktin. Etiketa e ushqimit përmbledh një grup informacioni që përcjell tek konsumatorët karakteristikat e produktit dhe këto informacione mund të ndikojnë në vendimet rreth blerjes së produkteve ushqimore. Disa studime tregojnë për ekzistencën e një marrëdhënie të fortë midis etiketës ushqimore dhe sjelljeve të konsumatorit (Hoogland et al., 2007). Evolucioni i shoqërisë gjatë viteve të fundit, ka rezultuar në një ndryshim rrënjësor të nevojave dhe sjelljeve të konsumatorit. Përmes aktivitetit të blerjes dhe konsumit, konsumatorët shprehin kulturën e tyre dhe përcaktojnë identitetin e tyre duke treguar gjithnjë e më shumë vëmendje për aspektet sociale dhe mjedisore që lidhen me bujqësinë. Shumica e konsumatorëve thonë se ata janë të gatshëm të paguajnë më shumë për një produkt ushqimor që ata e perceptojnë si produkt që nuk ka efekte negative në shëndet, mjedis ose konsiderohet i cilësisë së mirë (Bialkova dhe Van Trijp, 2010; Grunert, 2011). Disa detaje mund të jenë të mjaftueshme për të rritur vlerën e perceptuar të produktit, siç janë teknologjitë e reja për gjurmimin e produktit ose risitë e produktit. Sipas këtij skenari, etiketa është mjeti më i fuqishëm që prodhuesit të transmetojnë informacionin tek konsumatori (Banterle et al., 2013). Në Bashkimin Evropian, vullneti për të mbrojtur dhe promovuar prodhimin e ushqimit ka lejuar zhvillimin e një sistemi efikas të gjurmimit. Më këtë sistem të rregullave përmes etiketeës që siguron informacione të ndryshme, është e mundur të 
përmirësohet siguria e ushqimit dhe të rritet besimi i konsumatorit përveç dhënies së një vlere më të lartë për produktet ushqimore (Louriero et al., 2007). Sidoqoftë, tani është konstatuar se konsumatorët e perceptojnë gjurmueshmërinë si një atribut të cilësisë që duhet të merret në konsideratë në kohën e blerjes. Duket e qartë se gjurmueshmëria e produkteve ushqimore bie në mesin e atributeve të besimit. Modeli Total i Cilësisë së Ushqimit nga Grunert (Grunert, 2002) e konsideron cilësinë e ushqimit si një ndërtim shumëdimensional të karakterizuar nga katër dimensione themelore të ndërlidhura që janë: karakteristikat e ushqimit, shëndeti dhe procesi i prodhimit. Veçanërisht, dimensioni që ka të bëjë me proceset e prodhimit përdor atribute ushqimore që janë tipare të besimit sepse është e pamundur që konsumatori të jetë i vetëdijshëm për të gjithë procesin e prodhimit. Pra, etiketimi i produkteve ushqimore po bëhet gjithnjë e më shumë një element strategjik për diferencimin e produkteve në të gjithë zinxhirin e furnizimit, pasi që ndikon në sjelljen strategjike të prodhuesve që janë pjesë e zinxhirit të furnizimit dhe vetë evolucionit të etiketës. Roli i etiketës është thelbësor për të siguruar informacion të saktë në lidhje me produktet ushqimore.

\section{Etiketat e cilësisë}

Burimi kryesor i informacionit për të gjitha temat përkatëse në lidhje me etiketimin e ushqimit supozohet që është interneti (por jo për ushqimin në përgjithësi). Deri më tani konsiderohet si burimi më i rëndësishëm ku konsumatorët do të kërkojnë informacion por jo të gjithë mund të jenë kuriozë për të marrë më shumë informacione mbi ushqimin në përgjithësi dhe etiketat e cilësisë. Por, ekziston një grup i veçantë i konsumatorëve i cili është më i etur për të marrë informacion. Madhësia e këtij grupi mund të ndryshojë dhe varet nga publiciteti i përgjithshëm, zhvillimet aktuale në sektorin e ushqimit si dhe frika ndaj ushqimit siç diskutohet nga Böcker dhe Hanf (2000), zhvillimet teknologjike në përpunimin e ushqimit etj. Konsumatorët zakonisht nuk janë në gjendje të vlerësojnë cilësinë e produkteve ushqimore para blerjes, prandaj ata përdorin shenja cilësore si markat, çmimet ose etiketat (Steenkamp, 1990; Grunert dhe Aachmann, 2016). Për të ndihmuar konsumatorët në vlerësimin e tyre të cilësisë, BE prezantoi etiketa të rëndësishme të cilësisë përkatësisht PDO ose PGI dhe TSG. 
Për më tepër, secili vend po përdor tashmë etiketat e cilësisë kombëtare. Etiketimi i ushqimit në BE ka aspekte të ndryshme, p.sh., për të përmbushur kërkesat e gjurmueshmërisë, informimi i konsumatorëve në lidhje me aspekte të caktuara (p.sh. pa OMGJ), përmbajtja e informacioneve ushqyese etj.

\subsection{CILËSIA E SHËRBIMIT DHE KËNAQËSIA E KLIENTIT}

\section{Ḉmimi}

Në zgjedhjen e një produkti ushqimor, çmimi luan një rol të rëndësishëm. Cmimi është një vlerë ose shpërblim i ofruar në këmbim të kënaqësisë për industrinë ushqimore. Pra, në të gjitha rastet çmimi dhe dëshira e konsumatorit duhet të jenë në përputhje. Nuk është e thjeshtë të merren vendime rreth çmimit për një produkt ushqimor sepse vlerat thelbësore të mallrave në dispozicion përdoren për të vlerësuar çmimin i cili është thelbësor për kënaqësinë e konsumatorit. Kjo ndodh pasi që çmimi është faktori më i spikatur për të ndihmuar konsumatorin të marrë një vendim përfundimtar rreth produktit. Nga pikëpamja e konsumatorit, çmimi funksionon si një indicator për të përcaktuar përvojën e konsumatorit me mallra ose shërbime (Mattila \& O’Neill, 2003, 324). Pra, konsumatorët janë më të prirur ta bazojnë vendimin e tyre të blerjes në faktorin e çmimit se sa në ndonjë gjë tjetër (Khan, 2011). Sipas Skindaras (2009, 3), ne hasim në shumë produkte të llojllojshme që kanë nivele të ndryshme çmimesh. Në Marketing Mix, çmimi është një nga katër $\mathrm{P}$ - të që luan një rol të rëndësishëm në zbatimin e strategjisë së marketingut (Kottler \& Armstrong, 2012).

\section{Cilësia e shërbimit}

Shkalla në të cilën konsumatorët mund të kënaqen nga ofruesit e produkteve përfshin përgjegjësi dhe shërbim. Dëshira për të ndihmuar klientët është ajo që quhet përgjegjësi dhe shërbim i cilësisë së mire (Armstrong, 2012). Konsumatorët e vlerësojnë shumë kur një shërbim është përmbushur menjëherë, gjë që kuptohet mire nga ofruesit e shërbimeve të mira (Iqbal et al., 2010). 


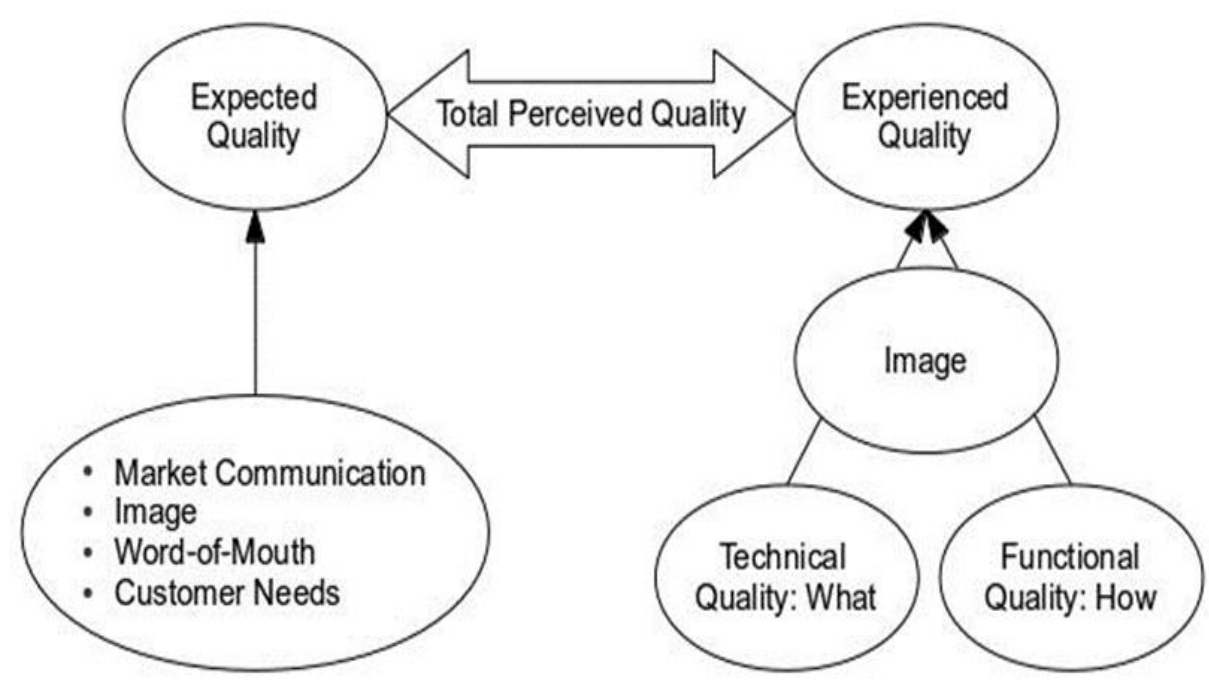

Figura 3. Modeli i cilësisë së shërbimit Grönroos (1990)

Për të krahasuar pritjet e konsumatorit, qasja më e mire për të matur cilësinë e shërbimit është instrumenti SERVQUAL. Ky instrument ndihmon në vlerësimin e perceptimit të klientit ndaj shërbimit aktual të dhënë nga kompania. Parasuraman, Valarie Zeithaml dhe Len Berry prezantuan këtë qasje në vitin 1988 për të matur shkallën e performancës në zonën e shërbimit. Cilësia e shërbimit do të jetë e ulët nëse pritshmëria e konsumatorit është më e lartë se perceptimi i shërbimit të tyre (Parasuraman, Zeithaml \& Berry, 1985). Sipas Nyeck, Morales, Ladhari dhe Pons, ky instrument përpiqet të matë dhe të vendosë hipoteza mbi performancën e shërbimit të një produkti. Fillimisht, ishin dhjetë dimensione mbi të cilat ishte realizuar SERVQUAL, por në vazhdim numri i dimensioneve të tilla është zvogëluar në pesë, të cila janë si vijon: 


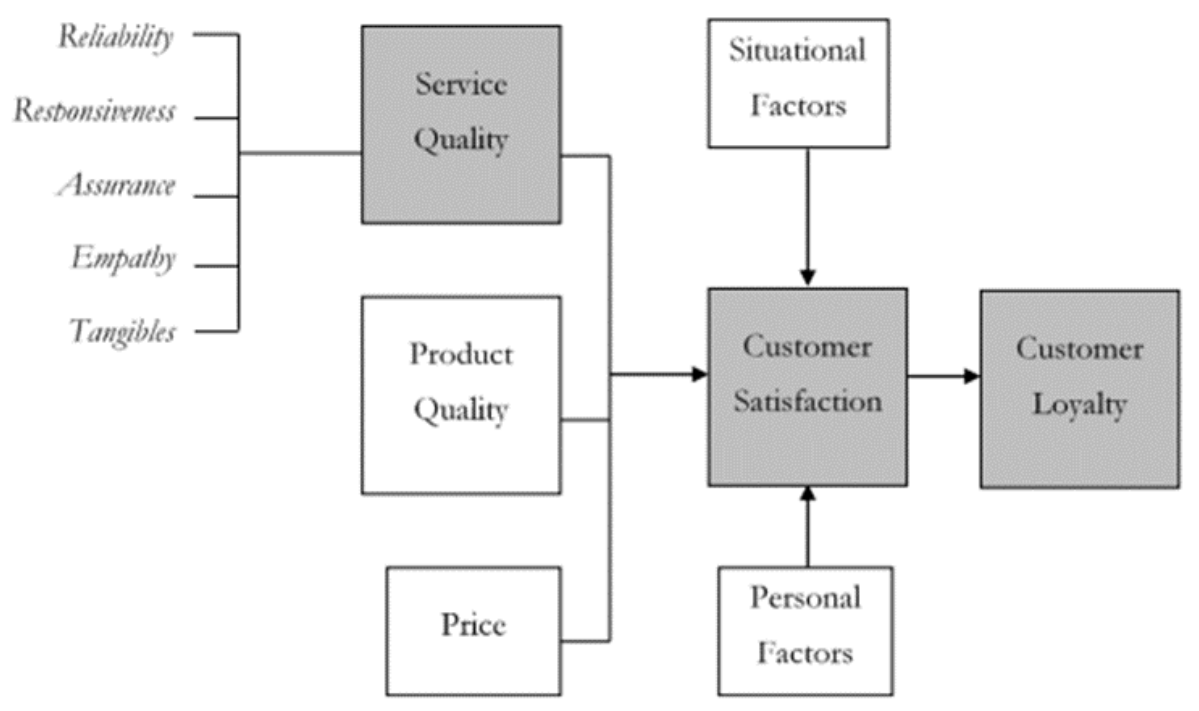

Figura 4. Modeli SERVQUAL (Parasuraman et al., 1988)

1. Besueshmëria: i referohet aftësisë për të kryer shërbimin e dhënë në mënyrë të saktë dhe të besueshme siç janë regjistrimet dhe faturimet.

2. Sigurimi (besueshmëria, mirësjellja dhe kompetenca): Ky dimension shoqërohet me mënyra dhe informacion të punëtorëve, si dhe aftësitë dhe tiparet e tyre për të siguruar besim te konsumatorët.

3. Mjetet fizike: Nënkupton punonjësit, pajisjet dhe pajisjet fizike të kompanisë.

4. Ndjeshmëria (përfshirë mirëkuptimin, komunikim dhe inkuadrimin e konsumatorit): i referohet vëmendjes së individualizuar, përkujdesjes dhe mirëkuptimit që kompania iu jep konsumatorëve të saj.

5. Përgjegjësia: i referohet gatishmërisë për të ofruar shërbim të vazhdueshëm dhe të shpejtë për të ndihmuar konsumatorët (Van Iwaarden, Van der Wiele, Ball \& Millen, 2003). 


\section{Përmbushja e kërkesave të konsumatorëve}

Ekspertët kanë përcaktuar kënaqësinë e konsumatorëve në shërbime si shkalla në të cilën janë përmbushur prirjet e konsumatorëve përmes performancës së shërbimeve (Santouridis \& Trivellas, 2010). Njohja e nevojave të konsumatorëve është shumë domethënëse sepse pikat e forta dhe të dobëta të biznesit mund të vlerësohen përmes saj. Për më tepër, ndihmon në përmirësimin e performancës së mallrave dhe shërbimeve si për klientët ashtu edhe për punonjësit. Përveç njohurive për pikat e forta dhe të dobëta të biznesit, ky aktivitet gjithashtu përpiqet të nxisë konkurrencë bazuar në ato pika të përcaktuara. Sipas Deng et al (2009), përmbushja e kërkesave të konsumatorëve është një pjesë shumë e rëndësishme e organizimit të biznesit sepse biznesi gjeneron shumë të ardhura nga industria kur konsumatori është i kënaqur nga shërbimet që iu ofrohen. 


\section{METODOLOGJIA E HULUMTIMIT}

\subsection{QELLIMI I HULUMTIMIT}

Qëllimi kryesor i këtij punimi është ekzaminimi i njohurive të konsumatorëve për sigurinë dhe cilësinë e produkteve ushqimore që ata konsumojnë apo blejnë. Në mënyrë që të realizohet tema e caktuar, është bërë një studim i pyetësorëve në territorin e Kosovës duke përfshirë 188 të anketuar të cilët ishin nga kategori të ndryshme të moshave. Në realizimin e këtij punimi për mbledhjen e të dhënave janë përdorur të dhënat primare të cilat janë mbledhur me anë të pyetësorëve të mbyllur, ku gjithsej kanë qenë 10 pyetje klasifikimi. Për një mënyrë sa më të lehtë për konsumatorët që të plotësojnë pyetësorët, ato janë përdourur në aplikacionin në internet të Google Forms. Informacionet sekondare janë marrë nga botimet shkencore dhe profesionale nga autorë të ndryshëm që trajtojnë çështjet e njëjta.

\subsection{OBJEKTIVAT E HULUMTIMIT}

Për të arritur qëllimin e hulumtimit kemi zgjedhur disa detyra:

$>$ Të analizojmë dhe të studiojmë këtë problem;

$>$ Të hartojmë anketën (pyetësorin), si mjet hulumtimi;

$>$ Të informohemi nga qytetarët;

$>$ Të grumbullojmë të dhëna përmes pyetësorëve;

$>$ Të bisedojmë me palët e interesit.

\subsection{DETYRAT E HULUMTIMIT}

Për të arritur qëllimin e këtij punimi dhe hulumtimin duhet të kryejmë disa detyra prej të cilave do të veçojmë:

$>$ Të analizojmë dhe studijojm përmbajtjet dhe të arriturat teorike ne lidhje me vitaminat dhe rendesin e tij tek qytetaret;

$>$ Të organizohet veprimtaria kërkimore në sistemin e aplikimit të instrumenteve si mjete të hulumitimit për grumbullimin e opinionit mbi temen në fjalë;

$>$ Prezantimi dhe paraqitja grafike e të dhënave

$>$ Interpretimi i rezultateve te hulumtimit 


\subsection{METODAT,TEKNIKAT DHE INSTRUMENTET E HULUMTIMIT}

Si metodë më të përshtatshme gjatë hulumtimit është aplikuar metoda e analizes teorike, induktive-deduktive, observativo-deskriptuese, statistikore si dhe metoda e bisedës.Si teknika të hulumtimit janë përdorur: anketimi, ndersa si instrumente janë përdorur: pyetësori.Të gjitha analizat statistikore janë punuar duke përdorur programi MS Excel.

\subsubsection{MOSTRA E HULUMTIMIT (POPULLACIONI)}

Popullacioni dhe mostra

Zhvillimi i hulumtimit është kryer në qytetin e Prishtinës në Kosovë.

Popullacioni i këtij hulumtimi janë qytetarët e Repubilkës së Kosovës, në komunën e Prishtinës. Mostra e këtij hulumtimi është numerikisht e caktuar (188 persona).

\subsubsection{Pyetësori}

1. Sa jeni të informuar rreth sigurisë së produkteve ushqimore?

2. Gjatë blerjes së produkteve ushqimore, a keni ndonjë shqetësim lidhur me faktin që mund të jetë i dëmshëm për shëndetin tuaj?

3. Gjatë blerjes së produktit ushqimor, a i lexoni informacionet të cilat ndodhen në paketimin e produktit ushqimor?

4. Gjatë blerjes së produkteve ushqimore, cilat informacione i kontrolloni vazhdimisht?

5. Cilat burime të informacionit i shfrytëzoni për zgjerimin e njohurive lidhur me cilësinë dhe sigurinë ushqimore?

6. Cilat aspekte mendoni se janë të rëndësishme për përcaktimin e sigurisë së lartë të ushqimit?

7. Në aspektin e sigurisë, a bazoheni në vendin ku janë prodhuar produktet ushqimore të cilat vendosni t'i konsumoni?

8. A mendoni se çmimi më i lartë i një produkti ushqimor nënkupton që produkti ka siguri dhe cilësi më të lartë?

9. Sa mendoni se janë të sigurta produktet ushqimore vendore?

10. Sa keni njohuri rreth standardeve që përdoren gjatë prodhimit të produkteve ushqimore? 


\section{PREZANTIMI DHE ANALIZA E REZULTATEVE}

Nga 188 të anketuar që morrën pjesë në realizimin e këtij studimi, 97 prej tyre ishin femra (51.6 $\%)$ dhe 91 ishin meshkuj (48.4\%). Prej të gjithë të anketuarve, shumica prej tyre ishin të moshës 21 - 30 vjeç (58.5\%), pastaj të moshës më pak se 20 vjeç (22.9\%), të moshës 41 - 50 vjeç (6.4 $\%)$, të moshës 31 - 40 vjeç (5.9\%), të moshës 51 - 60 vjeç $(5.3 \%)$ dhe më shumë se 60 vjeç $(1.1 \%)$. Pjesa më e madhe e tyre ishin nga zona urbane $(72.3 \%)$ ndërsa nga zona rurale ishin (27.7\%). Grupi I të anketuarve me arsim të lartë përfaqësohet nga (80.3\%), me arsim të mesëm të lartë $(17 \%)$ dhe me arsim të mesëm të ulët $(2.7 \%)$.

Tabela 1. Karakteristikat e të anketuarve

\begin{tabular}{|c|c|}
\hline Gjinia & $\%$ \\
\hline Femër & 51.6 \\
\hline Mashkull & 48.4 \\
\hline Vendi i banimit & $\%$ \\
\hline Qytet & 72.3 \\
\hline Fshat & 27.7 \\
\hline Mosha & $\%$ \\
\hline Më pak se 20 & 22.9 \\
\hline $21-30$ vjeç & 58.5 \\
\hline $31-40$ vjeç & 5.9 \\
\hline $41-50$ vjeç & 6.4 \\
\hline $51-60$ vjeç & 5.3 \\
\hline Më shumë se 60 & 1.1 \\
\hline Niveli i arsimit & $\%$ \\
\hline Niveli i arsimit të lartë & 80.3 \\
\hline Niveli i arsimit të mesëm të lartë & 17 \\
\hline Niveli i arsimit të ulët & 2.7 \\
\hline
\end{tabular}


1.Sa jeni të informuar rreth sigurisë së produkteve ushqimore?

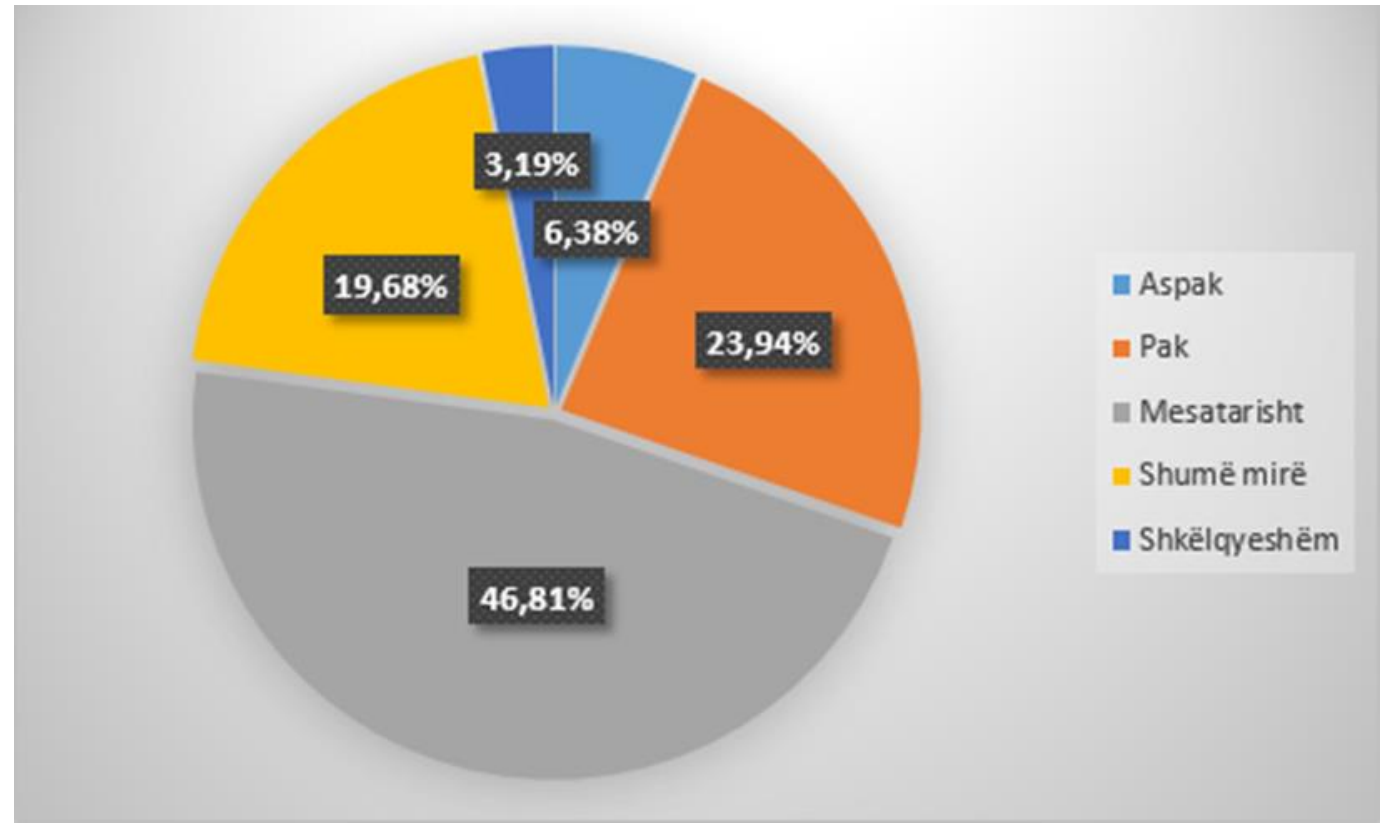

2.Gjatë blerjes së produkteve ushqimore, a keni ndonjë shqetësim lidhur me faktin që mund të jetë i dëmshëm për shëndetin tuaj?

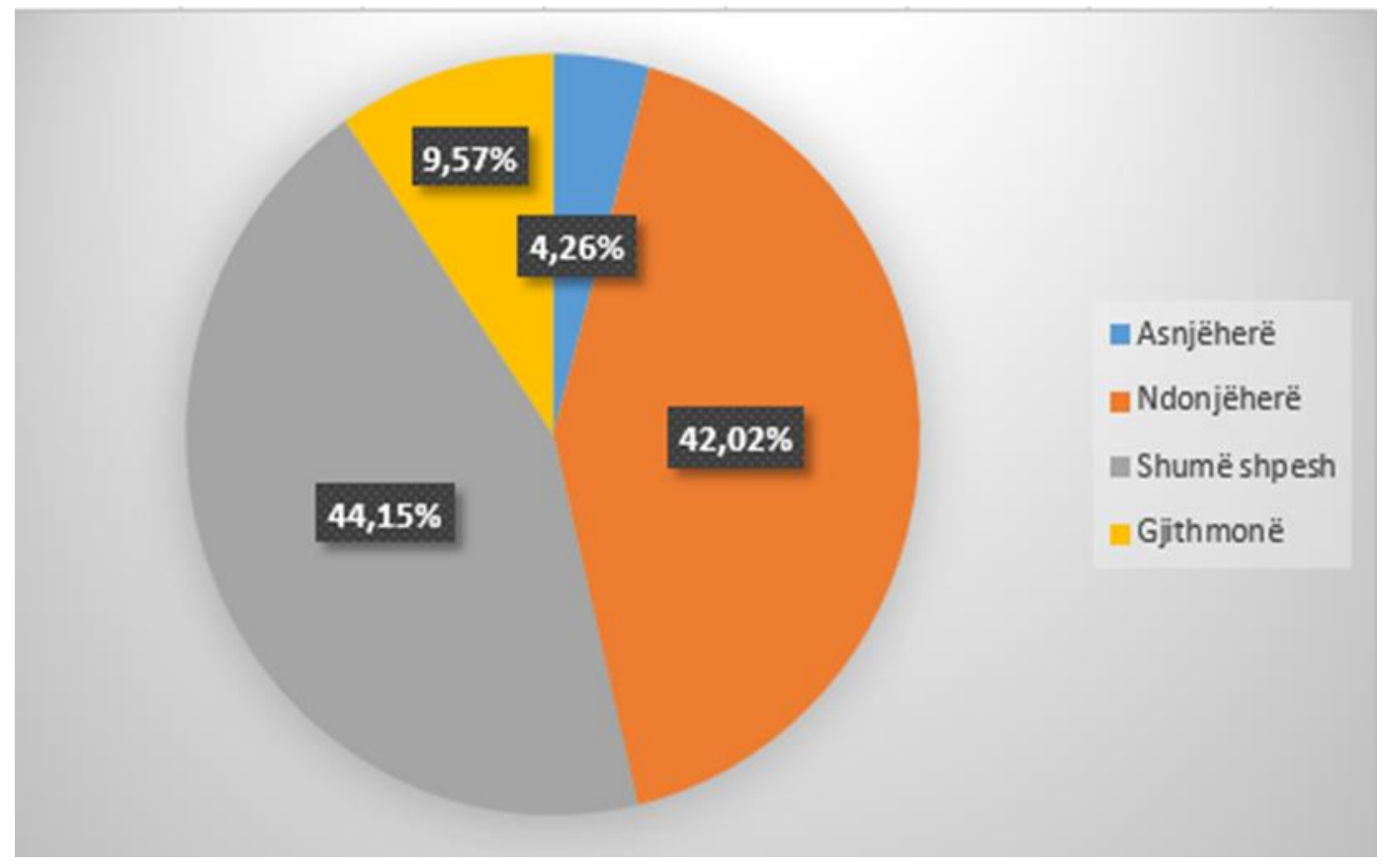


3. Gjatë blerjes së produktit ushqimor, a i lexoni informacionet të cilat ndodhen në paketimin e produktit ushqimor?

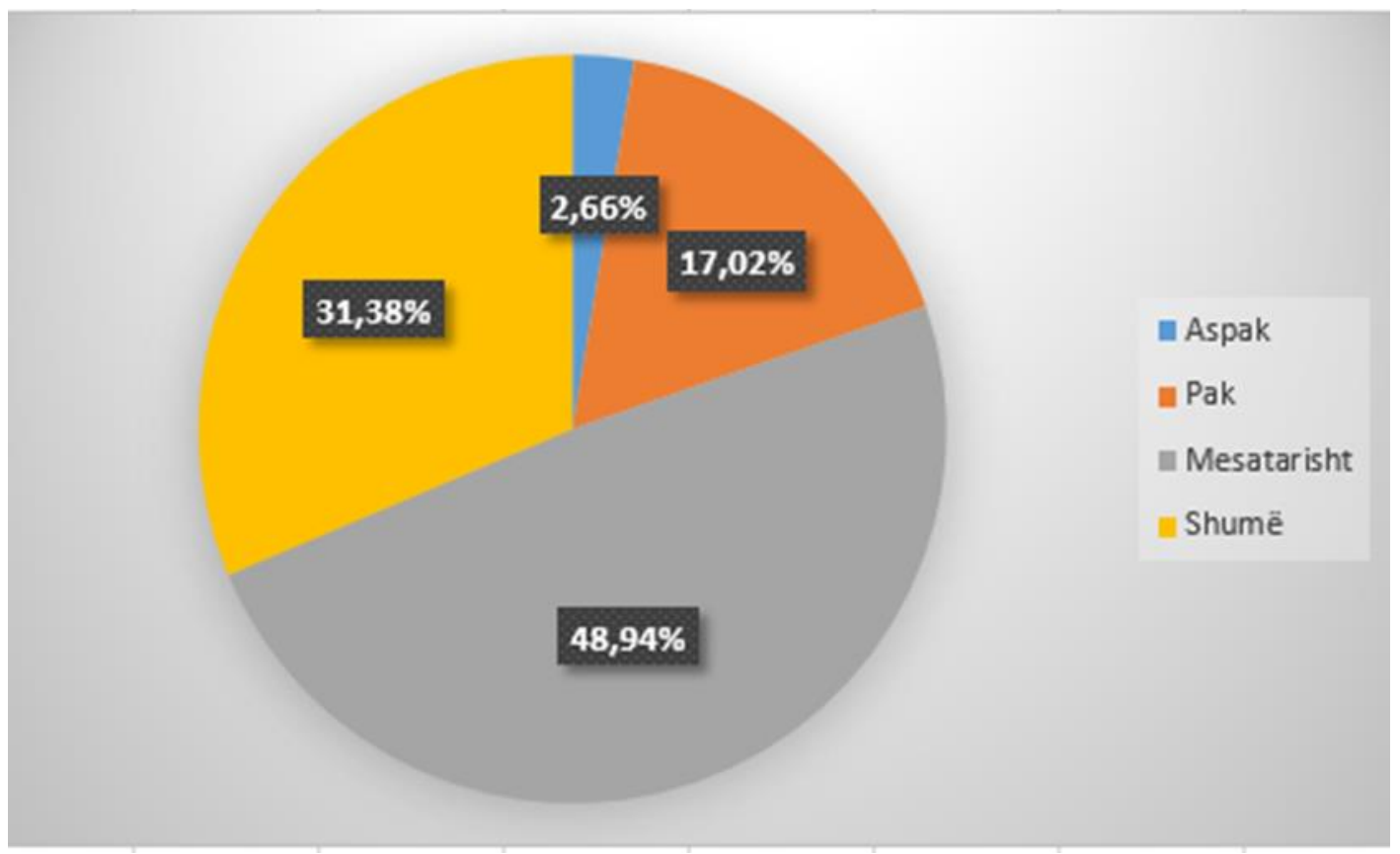

4. Gjatë blerjes së produkteve ushqimore, cilat informacione i kontrolloni vazhdimisht?

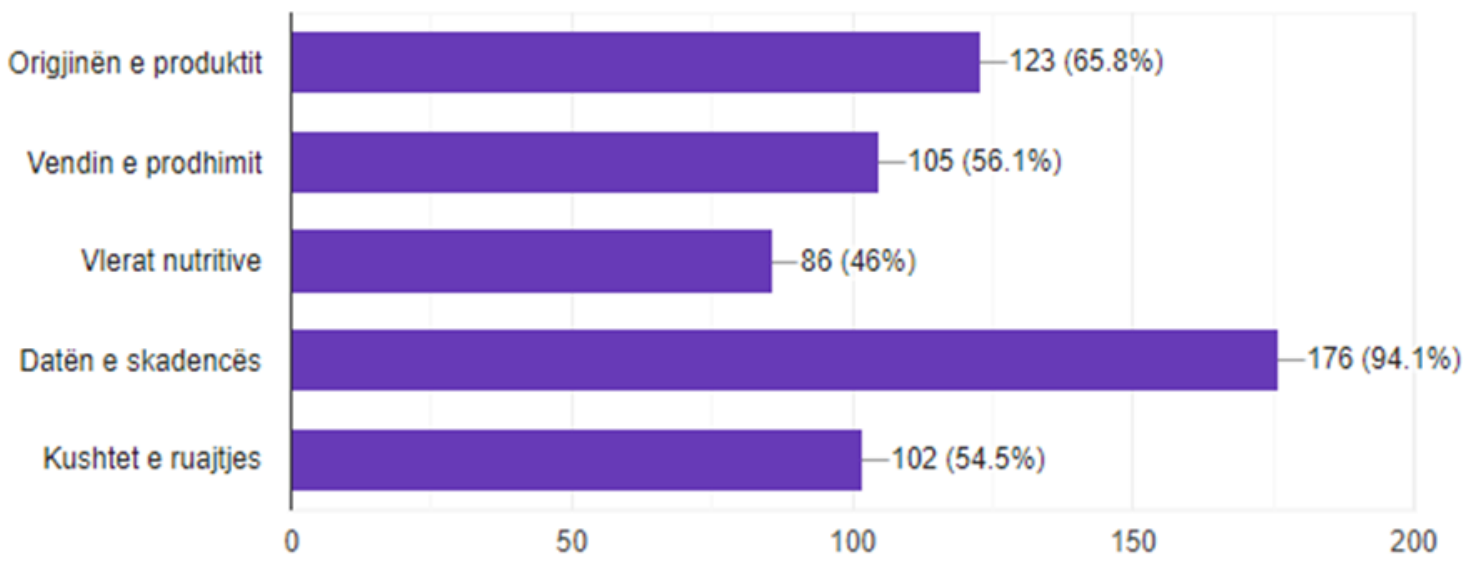


5. Cilat burime të informacionit i shfrytëzoni për zgjerimin e njohurive lidhur me cilësinë dhe sigurinë ushqimore?

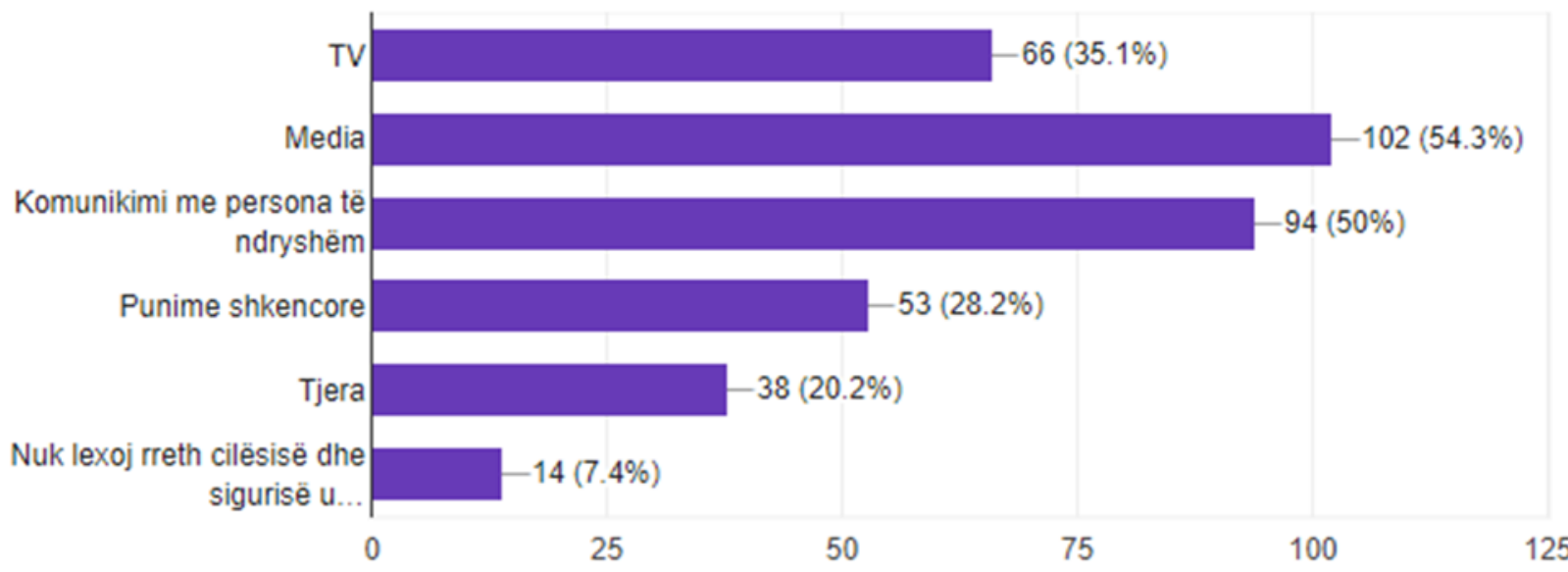

6. Cilat aspekte mendoni se janë të rëndësishme për përcaktimin e sigurisë së lartë të ushqimit? 1 - më pak rëndësi; 5 - më shumë rëndësi

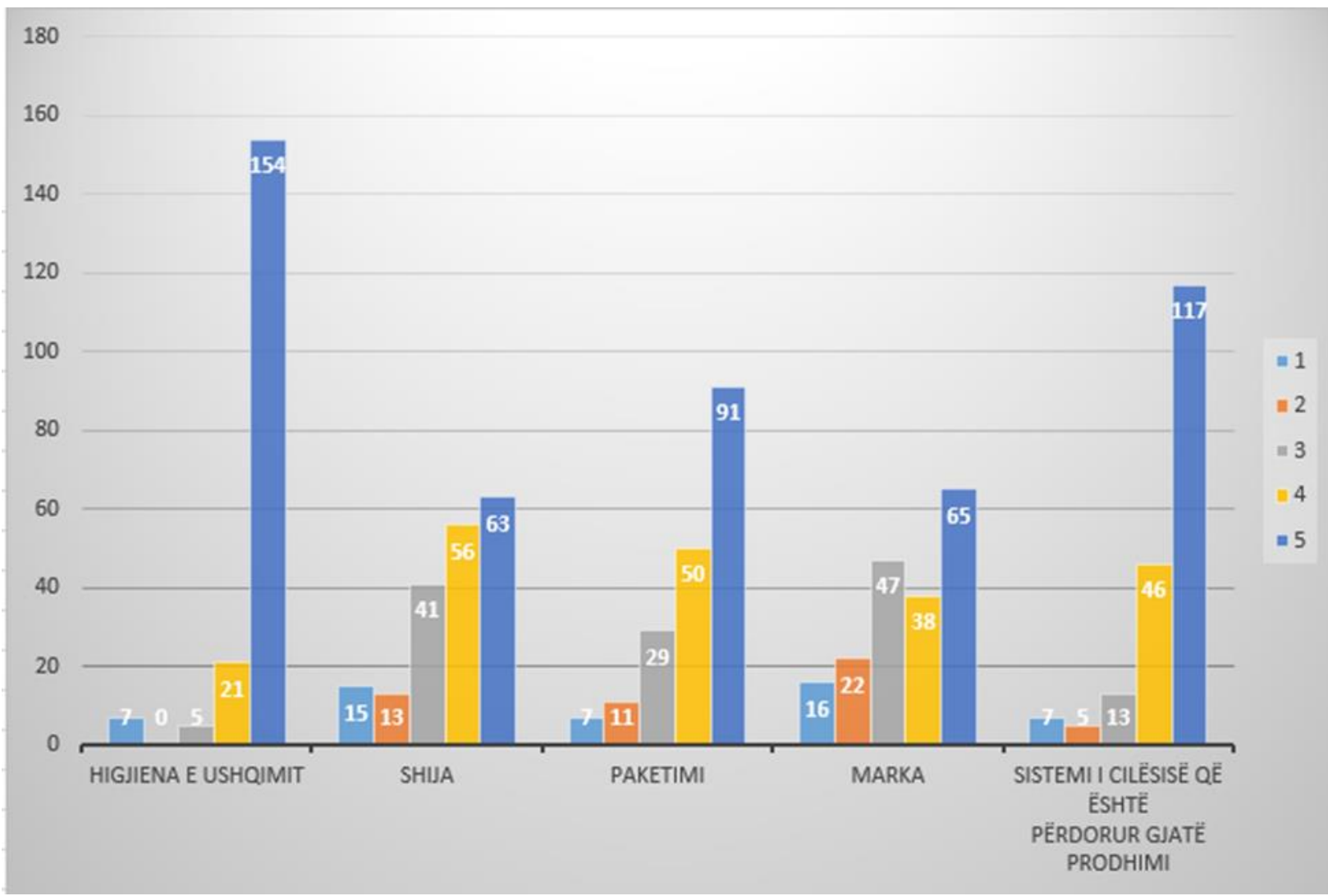


7.Në aspektin e sigurisë, a bazoheni në vendin ku janë prodhuar produktet ushqimore të cilat vendosni t'i konsumoni?

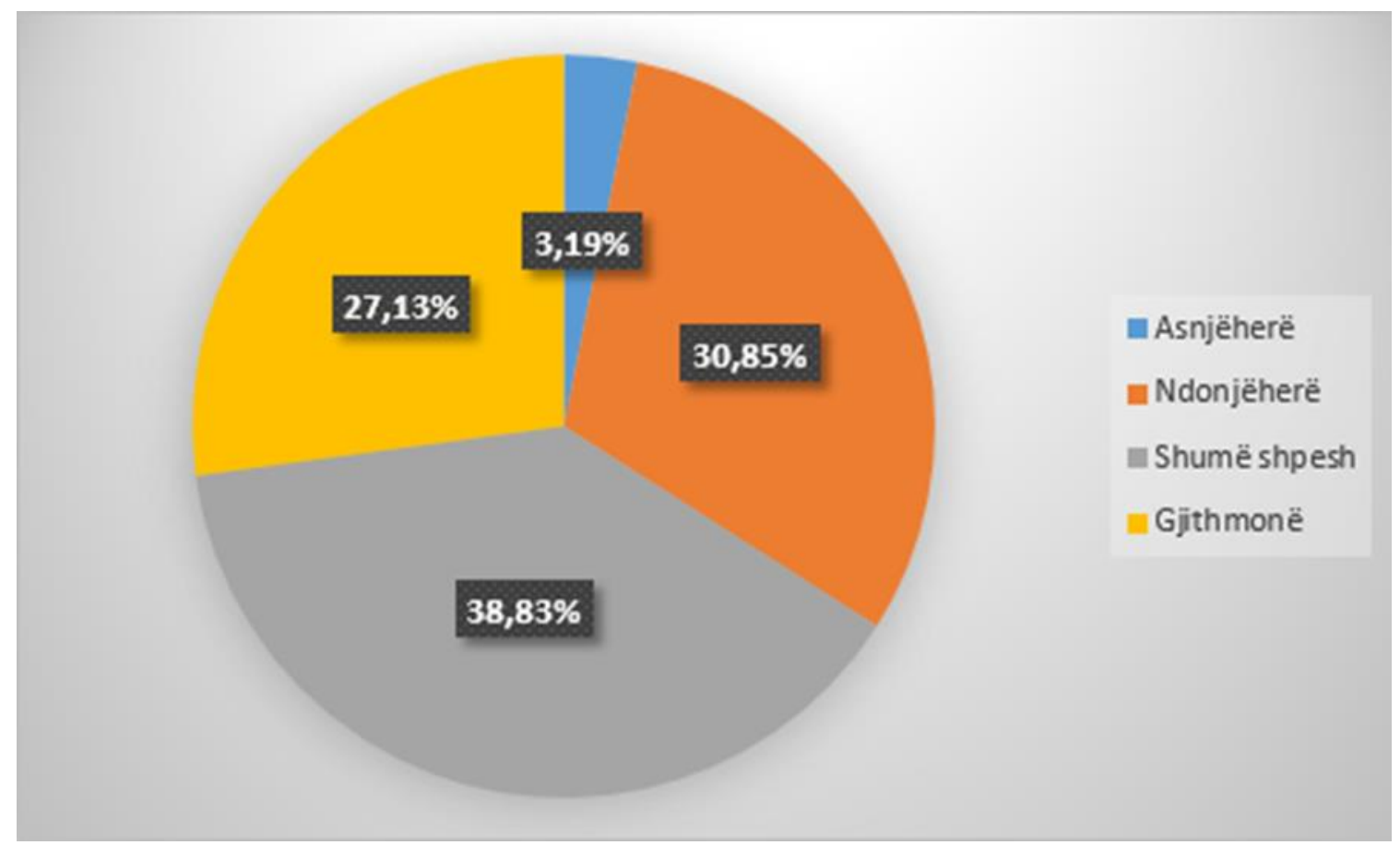

8.A mendoni se çmimi më i lartë i një produkti ushqimor nënkupton që produkti ka siguri dhe cilësi më të lartë?

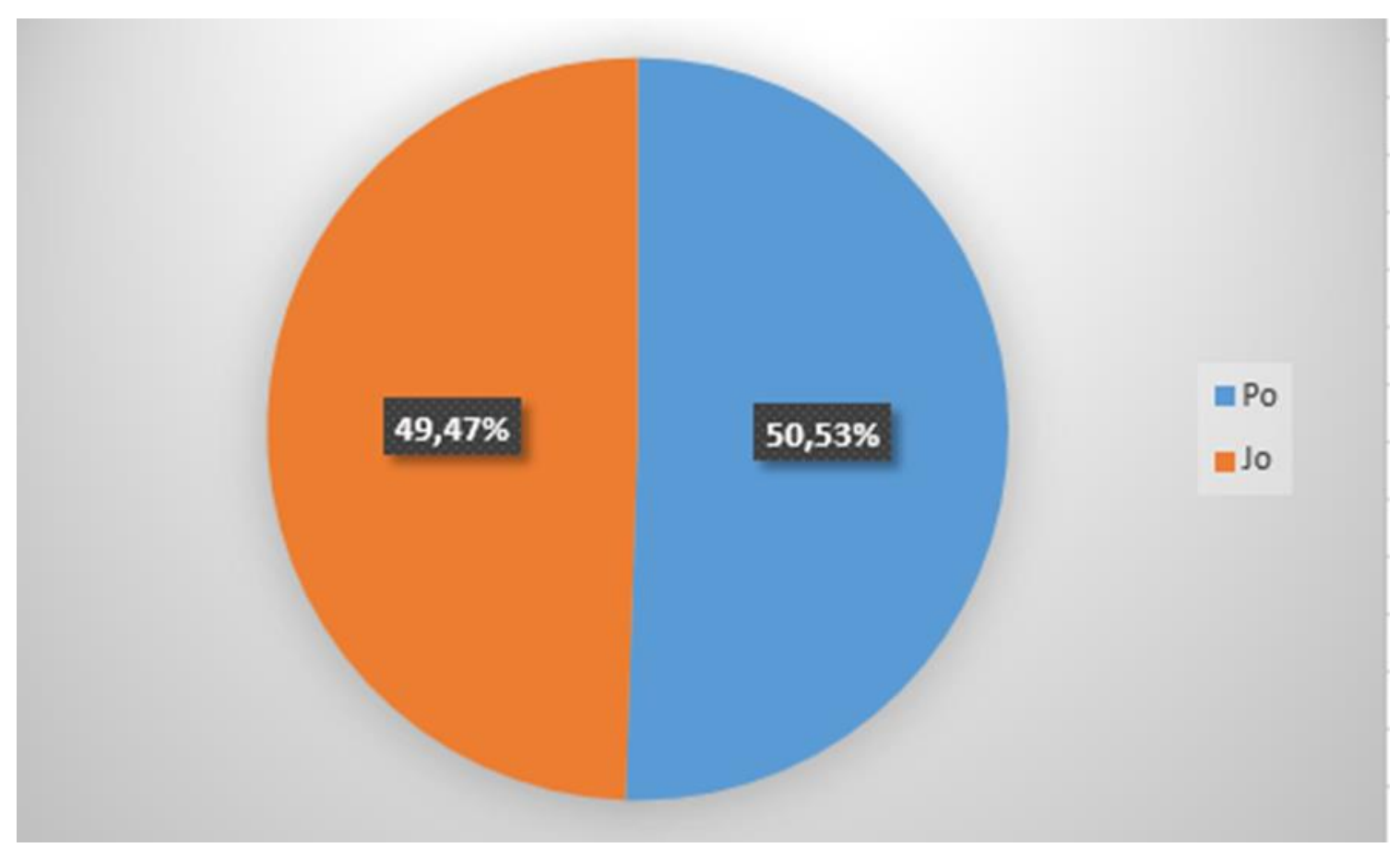

9.Sa mendoni se janë të sigurta produktet ushqimore vendore? 


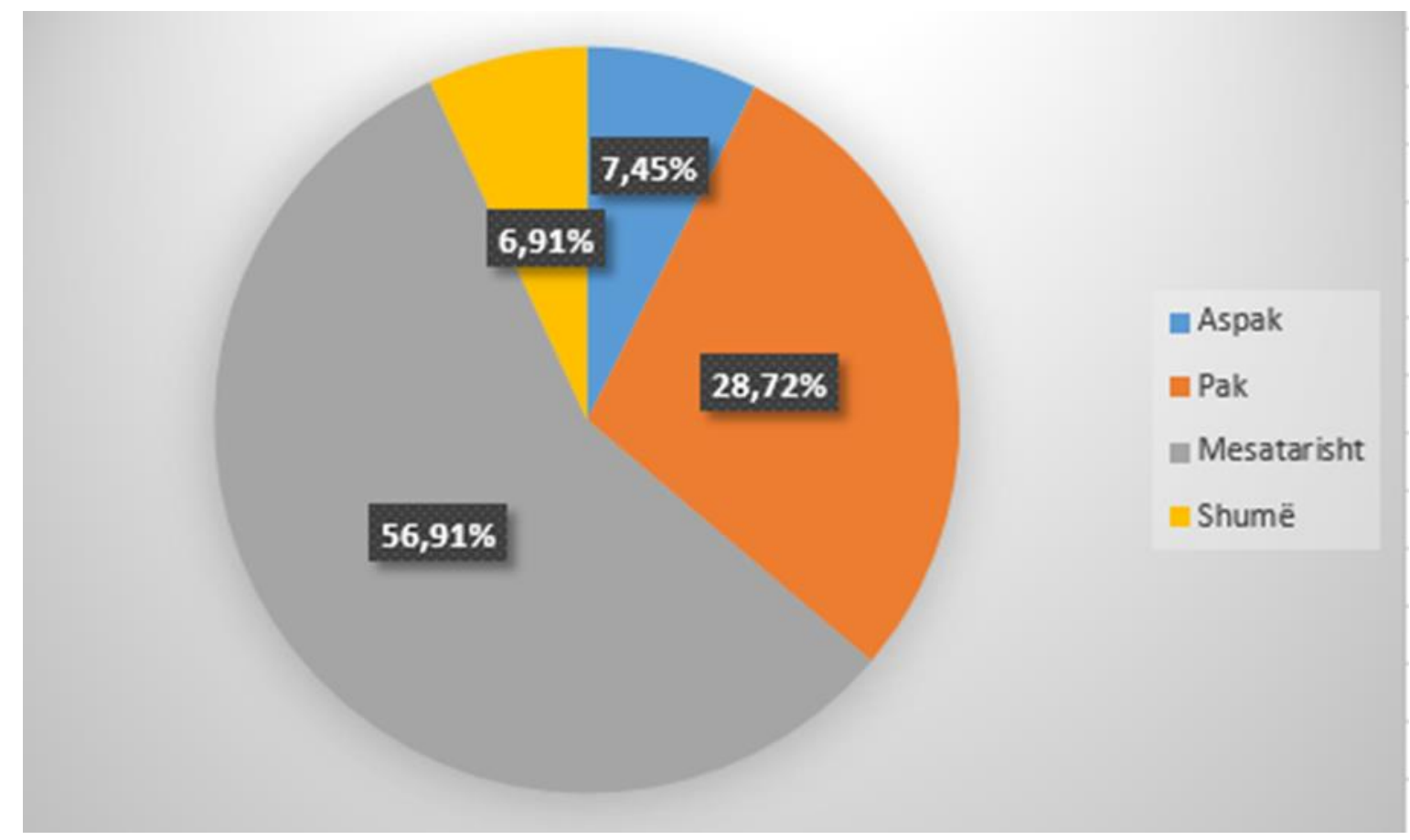

10.Sa keni njohuri rreth standardeve që përdoren gjatë prodhimit të produkteve ushqimore?

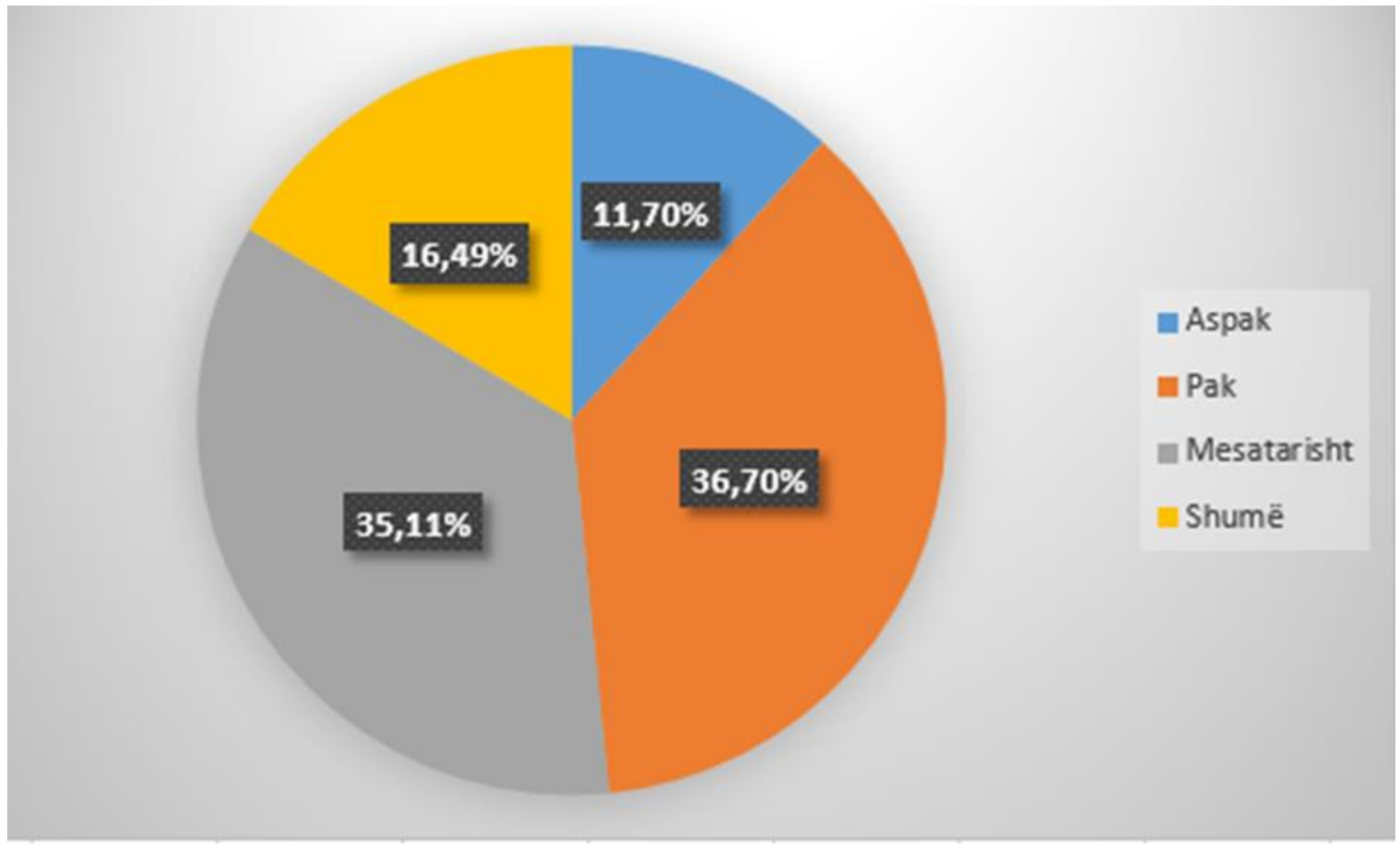

Sipas rezultateve të arritura, mund të arrijmë në disa përfundime të cilat janë: 
$>$ Pjesa më e madhe e të anketuarve mendojnë që kanë njohuri mesatarisht sa i përket temës së produkteve ushqimore

$>$ Rreth $44,15 \%$ e të anketuarve shprehin shqetësim lidhur me faktin se një produkt ushqimor mund të jetë i dëmshëm për shëndetin e tyre. Ky rezultat tregon që pjesa më e madhe e të anketuarve tregojnë përgjegjësi për produktet që vendosin t’i blejnë.

$>$ Shumica e të anketuarve i lexojnë informacionet në produktet ushqimore por jo gjatë gjithë kohës që blejnë produkte ushqimore

$>$ Data e skadencës është faktori dominues që kontrollohet vazhdimisht nga konsumatorët e anketuar ndërsa vlerat nutritive më pak.

$>$ Mediat dhe komunikimi me persona të caktuar janë format më të shpeshta që përdoren për pasurimin e njohurive lidhur me sigurinë ushqimore. Për fat të mirë, vetëm një pjesë e vogël janë përgjigjur që nuk janë të interesuar të lexojnë rreth sigurisë ushqimore.

$>$ Vendimet të cilat $\mathrm{i}$ marrin të anketuarit rreth produkteve ushqimore që do $t^{\prime} \mathrm{i}$ konsumojnë, në shumicën e rasteve bazohen në vendin se ku janë prodhuar.

$>$ Pjesa më e madhe e të anketuarve ende nuk kanë besim të plotë lidhur me sigurinë e produkteve ushqimore vendore. 


\section{KONKLUZIONE DHE REKOMANDIME}

Nga i gjithë ky studim, mund të arrijmë në përfundim që shumica e konsumatorëve të anketuar i kushtojnë vëmendje sigurisë dhe cilësisë së produkteve ushqimore që ata konsumojnë. Nga rezultatet e prezantuara në lidhje me temën që e kemi shqyrtuar mund të arrijmë në disa konkluzione:

$>$ Bazuar në përgjigjet e të anketuarve, 101 persona $(56,11 \%)$ që janë deklaruar se nuk kanë informacione të mjaftueshme rreth sigurisë ushqimore nuk i lexojnë informacionet që ndodhen në paketimin e produkteve ushqimore. Pra, mungesa e njohurive rreth sigurisë ushqimore rezulton në mungesë të vëmendjes rreth leximit të informacioneve.

$>$ Poashtu, 72 persona $(38,29 \%)$ që janë përgjigjur se nuk kanë informacione të mjaftueshme rreth sigurisë ushqimore, nuk kanë ndonjë shqetësim lidhur me problemet shëndetësore që mund të shfaqen si pasojë e produktit ushqimor të caktuar. Pra, mungesa e vëmendjes rreth problemeve shëndetësore që vijnë nga ushqimi është rezultat i pasurimit jo të mjaftueshëm të njohurive me informacione rreth sigurisë ushqimore.

$>$ Rreth 20 persona që janë deklaruar se sistemi i cilësisë që përdoret gjatë prodhimit të produkteve ushqimore nuk është një aspekt i rëndësishëm për përcaktimin e sigurisë së lartë të ushqimit, poashtu janë përgjigjur që nuk kanë njohuri të mjaftueshme rreth standardeve që përdoren gjatë prodhimit të produkteve ushqimore. Pra, mungesa e njohurive rreth standardeve që përdoren ka rezultuar në krijimin e opinionit se ato nuk kanë rëndësi në sigurinë ushqimore.

$>$ Disa nga rekomandimet e nevojshme të cilat mund të përmirësonin gjendjen që kanë konsumatorët në raport me sigurinë dhe cilësinë e produkteve ushqimore janë:

$>$ Të gjenden mënyra më të thjeshta të cilat i shpjegojnë në mënyrë më të thjeshtë informacionet rreth sigurisë dhe cilësisë së produkteve ushqimore të cilat mund të jenë të komplikuara për konsumatorët që vijnë nga fusha të ndryshme.

> Informimi më i hollësishëm i konsumatorëve në lidhje me efektet anësore shëndetësore që mund të shfaqen në rast të shmangjes së vëmendjes ndaj sigurisë ushqimore.

> Transmetimi deri tek konsumatorët i faktorëve që janë përcaktues në sigurinë ushqimore. 
$>$ Informimi konsumatorëve në lidhje me standardet që përdoren gjatë prodhimit të produkteve ushqimore. 


\section{REFERENCAT:}

[1] Ana, A., Josè, G., Tamburo, L. (2008). Food Safety and Consumers' Willingness to Pay for Labelled Beef in Spain.

[2] Christine, B., Howard, S. (1999). Consumer Food Safety Knowledge and Practices. Journal of Food Safety.

[3] B. Karen, B., Thomas, F., Klaus, G. (2002). Consumers' Food Choice and Quality Perception. The Aarhus School of Business. Pp. 5 - 11

[4] Lynn, F., Wendy, R. (2013). Emerald Article: Consumer Perceptions of Food Quality and Safety and their relation to traceability. British Food Journal.

[5] Jozev, G., L'udmila, N., Alexandra, A., Peter, Z., Jozef, P. (2018). Food Safety from Consumer Perspective: Health Safety. Potravinarstvo Slovak Journal of Food Sciences.

[6] Klaus, G. (2005). Food Quality and Safety: Consumer Perception and Demand. European Review of Agricultural Economics. Pp. 371 - 382.

[7] Slavica, G., Radoslav, G., Dorde, P., Jelena, G. (2013). The Importance of Consumers' Knowledge About Food Quality Labeling and Safety in Food Choice. Canadian Center of Science and Education.

[8] Elena, H., Johana, U., Renata, P. (2011). Consumers' Food Choice and Quality Perception: Comparative Analysis of Selected Central European Countries.

[9] Filipović, I., Njari, B., Kozačinski, L., Cvrtila, Ž., Mioković, B., Zdolec, N., Dobranić, V. (2008). Quality Management Systems in the Food Industry.

[10] Dipesh, K., Apil, P. (2018). How Food Quality, Price, Ambiance and Service Quality Effects Customer Satisfaction: A studi on Nepalese Restaurants in Finland. Haaga - Helia University of Applied Sciences. Pp. $7-13$.

[11] Renata, K. (2010). Drejtimi i Cilësisë në Industrinë Agroushqimore. Botime Maluka.

[12] L'udmila, N., Alexandra, A., Andrej, G., Peter, Z., Jozef, P., Ingrida, K., Jozef, G. (2018). Consumers Awareness of Food Safety. Potravinarstvo Slovak Journal of Food Sciences. 
[13] L'udmila, N., Jozef, G., Andrej, G., Jozef, P., Jozef, C., Zdenka, K. (2018). Food Safety from a Consumer's point of View: Food Quality. Potravinarstvo Slovak Journal of Food Sciences.

[14] Dacinia, P., Iris, V., Ruxandra, P. (2019). Consumer Understanding of Food Quality, Healthiness, and Environmental Impact: A Cross - National Perspective. International Journal of Environmental Research and Public Health.

[15] Ronald, S., Gary, R. (2003). Food Safety Handbook. A John Wiley \& Sons Publication.

[16] Tomas, S. (2018). Perception of Food Quality by Consumers: Literature Review. European Research Studies Journal. 